\title{
Technology Upgrading of Middle Income Economies: A New Approach and Results
}

\author{
Radosevic, Slavo and Yoruk, Esin \\ Pre-publication version accepted for publication in Technological Forecasting and Social Change \\ http://doi.org/10.1016/j.techfore.2017.12.002
}

\begin{abstract}
We explore issues of measurement for technology upgrading of the economies moving from middle to high-income status. In exploring this issue, we apply theoretically relevant and empirically grounded middle level conceptual and statistical framework based on three dimensions: (i) Intensity (ii) breadth of technological upgrading, and (iii) technology and knowledge exchange. As an outcome, we construct a three-pronged composite indicator of technology upgrading based on 35 indicators which reflect different drivers and patterns of technology upgrading of countries at different income levels. We show that technology upgrading of middle-income economies is distinctively different from that of low and high-income economies. Our results suggest the existence of middle-income trap in technology upgrading - i.e. countries' technology upgrading activities are not reflected in their income levels. Based on the simple statistical analysis we show that the middle-income trap is present in all three aspects of technology upgrading, but their importance varies across different aspects. A trap seems to be higher for 'breadth' of technology upgrading than for 'intensity' of technology upgrading and is by far the highest for the dimension of knowledge and technology interaction with the global economy. Finally, our research shows that technology upgrading is a multidimensional process and that it would be methodologically wrong to aim for an aggregate index.
\end{abstract}

Keywords: technology upgrading; composite index; R\&D and innovation; middle-income trap; structural change

Acknowledgement. Funding received from the European Union's Seventh Framework Programme (FP7/2007-2013) under grant agreement no 290657 "Growth-Innovation-Competitiveness: Fostering Cohesion in Central and Eastern Europe" (GRINCOH) is gratefully acknowledged. 


\section{INTRODUCTION}

Technology upgrading is a multidimensional process and the existing indicators, which are overly R\&D oriented, do not capture this multidimensionality. In particular, the existing indicators do not reflect specificities of technology upgrading of middle-income economies. They are either atheoretical or not rooted in stylised facts of technology upgrading and thus not relevant for low/middle-income economies. Radosevic and Yoruk (2016a) have developed empirically grounded middle-level conceptual framework which could illuminate type of challenges that are pertinent to a significant number of middle income and 'lower' high-income economies (from \$1000 - \$30000 GNI pc) in their path out of the broadly defined middle-income trap. In this paper, we apply this new framework and explore its robustness and validity to a sample of 42 economies of different income levels.

There is a variety of proposed composite indicators that measure countries' performance in growth, competitiveness and innovation. Examples are: the Global Competitiveness Index (GCR, 2015), the Knowledge Economy Index of the World Bank (Chen and Dahlman, 2004; Chen and Dahlman, 2005), the World Competitiveness Report Index (WCY, 2016), index of technological capabilities (ArCo) (Archibugi and Coco, 2004, 2005; Archibugi et al., 2009), the UNIDO Industrial Performance Scoreboard (UNIDO 2002; Lall and Albaladejo, 2002), Global Innovation Index, ${ }^{1}$ European Innovation Scoreboard ${ }^{2}$, the Technological Achievement Index of the UNDP (Desai et al., 2002), and the S\&T Capacity Index (STCI) proposed by the RAND Corporation ${ }^{3}$, the High-Tech Indicators (HTI) developed at the Georgia Tech Technology Policy and Assessment Center ${ }^{4}$.

However, this diversity of indexes has not led to a diversity of measurement outcomes. The similarity in ranking across different indexes are striking (Nasierowski and Arcelus, 2000). They all point to the importance of innovation to economic development, but differences in their conceptual perspectives do not change significantly ranking among countries. On the other hand, Archibugi et al. (2009) show that single indicator like R\&D can not substitute differences in ranking. So, despite similarities in rankings, the conceptual differences do matter. Based on these insights, we do not see the primary value of our contribution in a new ranking but in pointing to differentiated drivers of growth and technology upgrading at different income levels. This Schumpeterian approach is in intention similar to the WEF Global Competitiveness Index, which takes a differentiated view on the

\footnotetext{
${ }^{1}$ https://www.globalinnovationindex.org/

${ }^{2} \mathrm{http} / / /$ ec.europa.eu/growth/industry/innovation/facts-figures/scoreboards_en

${ }^{3} \mathrm{http}: / /$ www.rand.org/content/dam/rand/pubs/monograph_reports/2005/MR1357.0.pdf

${ }^{4} \mathrm{https}: / /$ tpac.gatech.edu/sites/default/files/projectfiles/HTI_S_2008report_Jun10.pdf
} 
role of technology across development path assuming that the closer countries are towards technology frontier, the more rest their growth and competitiveness on knowledge and technological activities. Our aim is not to focus on rankings per se but different drivers of technology upgrading. The learning effect should be in showing the diversity of drivers and compare countries regarding their upgrading paths. The ranking makes sense when comparing countries that are driven by similar drivers of technology upgrading or are at very similar stages of technology upgrading process.

We approach technology upgrading as a multidimensional conceptual framework which goes beyond R\&D in explaining the building of technology capabilities, which accompanies long-term growth. This concept is open to sensitivities of different levels of development and is empirically informed but also has some theoretical relevance. We consider it as an appreciative theorising framework, which aims to overcome a frequent weakness of composite indicators which is that they represent "measurement without theory" (Koopmans, 1947).

Our results show the relevance of three-pronged approach to technology upgrading as the process driven by the intensity and breadth of technology upgrading, which are complemented by the degree and differences in modes of technology and knowledge exchange with the global economy. Although statistically, it is possible to unite three dimensions of technology upgrading into a single index we remain sceptical regarding policy usefulness of such exercise. We show the positive relationship between three dimensions of technology upgrading and levels of income, but also the non-linear relationship between levels of individual indexes (dimensions) and levels of income. We identify middle-income trap in technology upgrading and through simple OLS, we quantify its weight across different dimensions of technology upgrading.

First, we explain in Section 2 the relationship between technology upgrading and technology gap literature. In Section 3 we explain the conceptual framework that lies behind the concept of technology upgrading. In Section 4, we describe individual indicators as well as applied method for constructing a three-pronged composite indicator of technology upgrading. In Section 5 we explore key stylised facts that emerge from the use of dataset that falls within our conceptual framework. In Section 6, we discuss the relevance of results and conclude. 


\section{THE RELATIONSHIP BETWEEN TECHNOLOGY UPGRADING AND TECHNOLOGY GAP}

\section{LITERATURE 5}

Similar to the literature on 'technology gap' our paper addresses the issue of accumulation of technological capabilities. For example in similar fashion to Fagerberg (1987), we show that there is a close relationship between a country's economic and technological levels of development. However, we are primarily concerned with the accumulation of technology itself and we do not aim to explore determinants of growth but we recognise that the nature of technology accumulation changes as countries grow. Similar to very recent work in 'technology gap' literature (Castellaci, 2011) we show that the interaction among different dimensions of technology is a crucial factor in technology upgrading. Technology gap literature assumes linear or log-linear relationship between technology variables and growth and postulates relationship across all income levels without exploring inflection points or threshold or middle trap levels (Fagerberg and Verspagen, 2002). However, we show that this relationship is not linear as we demonstrate the existence of middle income trap and show how that trap varies across three dimensions of technology upgrading. We show that three drivers of technology upgrading are qualitatively different.

Technology gap literature's ambition to explain determinants of growth has its price in several stark simplifications. First, innovation is highly varied at different income levels. In some specifications (Castellacci, 2011) innovation is equated solely with patents and scientific papers which we consider quite problematic, since this has implications for use in developing countries that we study. Second, the potential for diffusion (a possible source of convergence, proxied by the level of productivity or GDP per capita) is not directly measured but is proxied by the outcome variable - i.e. levels of productivity. This assumption implies automatic convergence which is quite different from the idea of middle-income trap. Third, in these models interaction with the global economy is ignored or is proxied through openness which in itself is highly problematic variable and endogenous to growth.

Technology gap literature uses the notion of absorptive capacity which is vague and is reduced on human capital and infrastructure.

\footnotetext{
${ }^{5}$ We are thankful to the anonymous reviewer for drawing our attention to the intricate links among the concepts of technology gap, technological capabilities and technology upgrading.
} 
On the other hand, the drawback of our approach is that we are not yet able to run regression models as we do not yet have enough long run series for meaningful testing of dynamics of relationships between growth and technology upgrading factors.

\section{A FRAMEWORK FOR MEASURING TECHNOLOGY UPGRADING: A CONCEPTUAL APPROACH}

We conceptualise technology upgrading as a three-dimensional process which consists of:

(i) Technology upgrading as depicted by intensity of production, R\&D and technology generation activities,

(ii) Breadth of technology upgrading, which is about diversity of technological knowledge, types of supporting infrastructure and organisational capabilities of firms which are the main carriers of technology upgrading, and

(iii) Knowledge inflows and outflows in and out of the economy through a variety of forms such as trade, FDI and disembodied knowledge flows.

All of the three dimensions have a strong grounding in the respective literature on firm-level technology upgrading, on structural change and growth, and on the integration of the global economy (see Radosevic and Yoruk, 2016a for overview and argument).

Technology upgrading is an outcome of the interaction between intensification of different types of technology activities (dimension I), structural factors and changes in this process (dimension II) which are mediated by the way economy interacts in this process with the global economy (dimension III). Given its three-dimensional nature the aggregate indicator of technology upgrading can be calculated statistically but as we show later on it is not justified conceptually and policy-wise. Especially, a third dimension (interaction with global economy) is a complementary dimension, i.e. it amplifies or reduces effects of technology upgrading depending on modes of integration or interaction with the global economy.

\subsection{INTENSITY OF TECHNOLOGY UPGRADING BY TYPES (SCALE)}

This dimension of upgrading is about acquiring different kinds of technology capabilities, which are also a reflection of the various technological levels of economies. Economies that operate behind technology frontier are more likely to grow based on production capability, not technology capability while high-income economies are more likely to grow based on technology frontier (technology capability and R\&D) activities. 
Three types of capabilities (production capability, technology capability, R\&D and knowledge intensity) are present in all economies to different degrees. Their importance as drivers of growth varies in dependence of achieved income and technology levels as well as of the structural features of economies.

\subsubsection{PRODUCTION CAPABILITY}

Production capability is the capability to produce with given level of technology at world levels of efficiency or productivity. It is different from technology capability and it requires primarily excellent operational efficiency (Bell and Pavitt, 1993). The key workforce to operational efficiency is skilled technicians or blue-collar workers. A more complex capability is product and process engineering, which involves improvement in existing products and processes. This ability is widely dependent on skilled engineers. Process and product engineering are still part of production capability as they are about incremental innovations, not changes in designs but improvements in products and processes.

We use as proxies for production capability ISO9901 certificates, trademark applications and assessment on the job training activities. ISO certificates are universal management standard, which indicates that there are in place businesses process which should guarantee operational efficiency though not necessarily its improvements. However, ISO adopters have far lower organisational death rates than matched firms within their industries, their sales and employment grew substantially more rapid post certification than at matched firms (Levine and Toffel, 2009). With the globalisation, they have spread as an internal mechanism of quality control and as a precondition for participating in global value chains (Stevenson and Barnes, 2001). They are also proxy for a variety of industry-specific standards which are difficult to aggregate. Terlakk and King (2006) show that they provide a way of communicating about unobservable firm attributes, thereby generating a growth effect for certified organisations.

Trademark applications are proxy for developed production capability but in the service sectors. They also proxy for marketing innovation and thus suggest that firm has differentiated production capability or brand (Millot, 2009; Mendonca et al., 2004). Baroncelli et al. (2004) et al. argue that the global distribution of trademarks is skewed toward high-income industrial countries and that they are concentrated in R\&D-intensive sectors such as pharmaceuticals, scientific equipment, and the chemical industry. Finally, on the job training is proxy for human capital capacity to work effectively with the given technology. It captures both in-firm training and specialised high quality professional training outside the companies. 


\subsubsection{TECHNOLOGY CAPABILITY}

A developed technological capability indicates a capacity to change product and processes significantly through the systematic innovation process. There is not a sharp boundary between R\&D and technology capability, but we can assume that technology capability is about development, not necessarily about research. The first stage of development is advanced development or prototype for manufacture which should be distinguished from exploratory development, which is about prototype in a system (Amsden and Tschang, 2003). There is a critical threshold level of capability required of firms to move from advanced development, which is development for manufacture to own design manufacture. Production capability, process and product engineering, and advanced development are doable within OEM enterprises while exploratory development is a feature of own design manufacturers (ODM).

The available proxies of development activities are resident and international patents and industrial designs. They are the right proxies because they are about development, but equally, patents have well-known biases (van Zeebroeck, 2011). A significant advantage of using patents is the length and consistency of time series derived as well as the possibility to identify technological fields or specialisations using the patent classification. Also, as countries move up towards technology frontier patenting becomes more necessary and is less relevant for countries behind technology frontier where IPRs are not the major form of protection of technological know-how. To capture domestic technological activities pushing the technology frontier we rely on EPO and USPTO data, which reflect technological activities relevant for competitiveness in international markets. To capture technological capability for technological development behind the technology frontier we use direct patent applications by residents to their respective national patent offices. In general terms (even though the patent strategies may differ from this rule) residents will directly apply for patents in their home countries disregarding applications abroad if their technological activities do not have global industrial relevance. So, the resident direct patent applications to national patent offices dominantly proxy technology effort behind the technology frontier. Countries that are behind technology frontier should have much higher share of resident patents, and their share of transnational patents is marginal. However, as countries move towards technology frontier their transnational patenting increases. This pattern may be somewhat different in very large catching up economies, where domestic patenting may continue to play an important role. However, their transnational patenting as a proxy for world frontier technology effort should continue to increase. ${ }^{6}$

\footnotetext{
${ }^{6}$ For example, Hu and Jefferson (2009) show that it is the level of technological development that ultimately carries the strongest weight in patenting which is very much along the lines that we use patent proxies.
} 
We use both EPO and USPTO data due to a geographic bias of patents. We do not use 'international' patents filed under the Patent Cooperation Treaty (PCT), or applications filed simultaneously at several national offices (e.g., the 'triadic families') as these are biased towards inventions of higher value, which are often owned by large firms. This would underestimate patenting of countries at lower income levels that do not have many big companies (van Zeebroeck, 2011).

\subsubsection{RESEARCH \& DEVELOPMENT}

$R \& D$ is usually considered as the major component of innovation and, therefore, one of the major drivers of growth. This model is the basis of new (endogenous) growth theory (Romer, 1990; Lucas, 1988). OECD (2003) landmark study shows that there is a clear positive linkage between private sector R\&D intensity and growth in the per capita gross domestic product (GDP) for OECD economies. However, there is no clear-cut relationship between public R\&D activities and growth, at least in the short term (ibid).

Research and development are usually treated as one category though this seems to be mainly due to statistical convention rather than a belief that research and development are indeed similar categories. Amsden and Tschang (20003) show that the Frascati definitions are not specific enough to allow an R\&D project to be classified accurately by conventional type (basic, applied and development). Under technological capability, we capture patents as they have intended commercial application. However, R\&D has far broader aims and its links to growth and productivity is far from straightforward. Literature conventionally accepts that R\&D has two faces (Cohen and Levinthal, 1989). One is as being the driver of world frontier innovation, and another one is R\&D as a driving force for imitation activities or as a factor of absorptive capacity. On that basis, it is assumed that R\&D is driver only of world frontier innovation but an only factor of absorptive capacity in industries that operate behind technology frontier. Griffith et al. (2004) on the example of twelve OECD countries find R\&D to be statistically and economically significant in both technological catchup and innovation. Kneller and Stevens (2006) find opposite also on the example of twelve OECD countries and conclude that the effect of R\&D on production is primarily through its contribution to the stock of Frontier knowledge itself in each industry.

However, Hu and Jefferson (2009) ignore the significant difference between external (transnational) applications from domestic applications by residents which forms important distinction in our case and is very important in the case of China (see Holmes, McGrattan and Prescott (2015) and middle income economies, in general. 
R\&D plays a different role in economies at various levels of development. For example, middleincome economies tend to grow more on imitation activities while transition towards high-income group requires a shift towards frontier technology activities. So, in both groups, R\&D plays an important but different role. In catching-up economies, R\&D has a much more important role in terms of absorptive capacity or capacity to use effectively knowledge from abroad in addition to its role as a driver of world frontier innovation. In catching-up EU economies, technology transfer activities are important drivers of innovation along with the non-R\&D-based innovation activities. Reinstaller and Unterlass (2010) show using CIS micro-data for 17 EU countries that the determinants of successful product innovation of European innovative firms vary across countries depending on how far they are from the technological frontier. Farther away from the technological frontier, technology transfer is more important than own R\&D; close to the frontier the cooperation with universities, own research, highly skilled personnel and intellectual property rights are paramount (ibid). However, Yoruk (2011) and Yoruk and Yoruk (2012) show that technology transfer and own R\&D (even with imitative aims) are complementary and as their level increase in firms in the country away from the technology frontier, both the number and degree of knowledge networks increase.

Given this evidence, the mainstream model of R\&D based growth like Crépon, Duguet and Mairesse (1998) or CDM model, which establishes the link between R\&D, innovation and productivity is theoretically grounded but does not capture non-R\&D drivers of growth, which are quite important in catching-up economies. R\&D remains relevant in the catching-up economies, but its role as the factor of absorptive capacity is much more prevalent when compared to its capacity as a driver of world frontier innovation. This is the main reason why we have to separate technological capability from R\&D, which has a much broader role in economic development.

We proxy R\&D through the following indicators, both 'hard' and subjective:" Business Enterprise Sector expenditures as \% of GDP; Research and development expenditure (\% of GDP); Researchers in R\&D (per million people); Technicians in R\&D (per million people); Science Publications: Scientific and technical journal articles; Science citations; and subjective assessment of Quality of scientific research institutions; and of University - Industry Collaboration.

\footnotetext{
${ }^{7}$ Subjective indicators are expanding the scope of our metrics of technology upgrading which otherwise would have been impossible to construct. Also, subjective indicators do not diverge from hard indicators as demonstrated by confirmatory factor analysis a(see Appendix C where all CFA values for indexes are above 0.78 ) and by $C$-alpha values in Tables 1 and 2 (all values are above 0.89 where hard and subjective indicators $\mathrm{mix}$ ). A problem could arise if we were testing dynamic model. Namely, subjective indicators are possibly more volatile over years due to a variability of perceptions depending on the overall macroeconomic sentiments. However, this could be controlled for by various time series techniques.
} 
It is important to bear in mind that that production, technology and R\&D capability are not hierarchically structured, i.e. moving from technology capability to R\&D or from development to research does necessarily involve higher technology complexity but merely qualitatively different set of technology or knowledge requirements. Equally, if not more important, upgrading to 'higher' stages are not automatically more rewarding regarding value added, i.e. upgrading may not necessarily lead to increased incomes but can simply be necessary to maintain the existing levels of income.

\subsection{BREADTH OF TECHNOLOGY UPGRADING: STRUCTURAL CHANGE, INFRASTRUCTURE AND FIRMS' STRUCTURE (SCOPE)}

Technology upgrading is about changes in technology intensity but equally about structural change. In fact, these two are inextricably linked. The process of technology upgrading is a process of diversification of technological knowledge, of increased organisational diversity and specialisation. Technology diversification is an expansion of technology base into a broader range of technology areas.

\subsubsection{INFRASTRUCTURE: HUMAN CAPITAL, PHYSICAL AND ORGANISATIONAL}

Technology upgrading is primarily taking place in firms, but it is not only firm-level business. The accumulation of technology capability in companies must be accompanied by an organisational and institutional infrastructure that supports the acquisition of such capabilities. Choung et al. (2014) show that transition from the adoption (catching-up) to the creation stage (post-catch-up) depends on the range of infrastructures that support innovation in a country, in addition to the strategy and resources of a single company. We consider infrastructure to be a major dimension of structural change. Infrastructure upgrading is essential element or externality of technology upgrading. Inefficiencies in infrastructure can hinder otherwise competitive firms to upgrade.

Human capital can also be considered a very specific type of 'infrastructure' or precondition for technology upgrading. Technology embodied in new machinery and equipment will not by itself lead to increased productivity unless there are human skills to use effectively and improve it. Also, to be effective human skills need to be part of a specific organisational and economic process that rewards dexterity, learning and innovation (Lazonick, 2002). So, human skills unless converted into firmspecific skills will not suffice for technology upgrading. Still, a human capital acquired through education can be considered an infrastructural precondition or input into technology upgrading. 
Another structural precondition for technology upgrading is physical infrastructure. Infrastructure generates significant externalities to firms' transaction costs. It is both public good and input in the production of other intermediate inputs. Access to infrastructure services strongly correlates with a country's average income (Griibler, 1990). As countries reach certain stages of economic development the extent to which infrastructure may represent binding constraint to their development changes. Thirty out of 32 studies of OECD countries found a positive effect of infrastructure on some combination of output, efficiency, productivity, private investment and employment (Romp and de Haan, 2005).

This dimension of technology upgrading is proxied by human capital indicators (average years of schooling of those over 25y age, subjective assessment of the quality of maths and science education, of availability of research and training services, of availability of scientists and engineers. Physical infrastructure is proxied by fixed broadband Internet subscribers (per 100 people) and by Gross Fixed Investment as \% of GDP.

\subsubsection{STRUCTURAL CHANGES: TECHNOLOGY DIVERSIFICATION, CHANGES IN THE DEMAND AND SUPPLY OF INNOVATION}

There is not a general theory of structural change but a variety of theoretical approaches to different methodological nature that aim to explain structural shifts between three broad sectors and among industries within these sectors (Krueger, 2008). There is a common understanding that technological changes affect structural change in the way that industries with relatively lower rates of productivity growth tend to shrink regarding shares while those with higher rates of productivity growth expand. In this way, structural change promotes aggregate productivity growth even if we assume that within industries productivity growth remains stagnant. However, the empirical evidence on the role of structural change in aggregate productivity growth escapes broad generalisations and differs very much across different periods and countries or regions.

So, despite the recognised importance of structural change, we can derive very little in the way of the importance of different sectors and industries in economic growth. The whole point of structural change driven by technology is that it changes boundaries of industries as well as the nature of industries. Hence, using high tech, as a proxy for structural change would be highly misleading as high-tech elements permeate many low-tech sectors. Also, catching-up countries are involved increasingly in high-tech industries but at low value added segments. Similar to this, the share of ICT industries in industry structure or export would be highly misleading as it ignores value added levels. So, instead of focusing on structural changes at the level of industries we prefer to focus on more 
reliable trends regarding technological changes. By this, we mean primarily technological diversification as reflected in changes in the structure of patenting as well as level and changes in subjective perceptions of demand and supply of technologies. So, we construct Herfindahl index of concentration to measure shifts in the patenting structure of WIPO, EPO and US patents. We also use subjective perceptions of buyer sophistication; of changes in buyer sophistication; of assessment availability of state-of-the-art technologies as a proxy for supply as well as shifts in the availability of latest technologies.

\subsubsection{FIRM LEVEL ORGANISATIONAL CAPABILITIES}

Firms are the main agents of the innovation process. This structural feature of economies is ignored in understanding determinants of growth and technology upgrading. Usually, innovation is associated with new technology-based firms while the role of big business is largely ignored. The changing interaction between large and small businesses during development is a very much unexplored topic. A quite new way of looking at the role of big business in catch-up is Lee et al. (2013), who look at the big business as one of the binding constraints to growth, especially in countries that are presently in the so-called middle-income trap.

Lee et al. (2013) show that the big businesses, and not SMEs, exert an independent and robust effect on economic growth. Wealthy countries tend to have larger numbers of big businesses than predicted by their sizes while_many middle-income or non-members of the OECD tend to have negative residual numbers or a lesser number of big businesses than predicted. In overall, the econometric evidence suggests that a big business plays a more robust role in the economy than SMEs. However, they also show that the excessive relative dependence on big businesses does not seem to be good either.

Overall, organisational variety in the economy does matter for technology upgrading and should be included in determinants of technology upgrading as one of the structural variables. This does not deny the importance of SMEs but suggests that SMEs alone are insufficient as drivers of technology upgrading. Big business plays a crucial role in structural transformation especially through diversified business groups, which are present in all middle-income economies (Morck et al., 2005). They are carriers of usually missing organisational capabilities in middle-income economies, which are an essential ingredient of technology upgrading (Khanna and Yafeh, 2007; Amsden and Hikino, 1994).

This sub-component of technology upgrading is proxied by two indicators. First is the number of Forbes 2000 companies per million of the population, which indicate the relative share of organisational capabilities in the economy. A second indicator is a subjective assessment of firm- 
level technology absorption. This indicator 'picks up' countries that do not have Forbes size firms in their economy but where subjective assessment of companies' technology absorption capability can be used as a substitute.

\subsection{INTERACTION WITH GLOBAL ECONOMY AND TECHNOLOGY UPGRADING}

A successful technology upgrading is never entirely independent process but is always linked to the inflow of foreign knowledge skills, which are coupled with intensive domestic technology effort (Radosevic, 1999). Literature that documents that are far too lengthy and only a few examples will suffice to reiterate this robust but often forgotten stylised fact (Mowery and Oxley, 1997; Kim, 1997; Amsden, 2001). The emphasis is usually on one of these two elements of catching up - either on domestic technology accumulation or inflows of foreign knowledge through trade, Foreign Direct Investment (FDI) and open economic regime.

The literature on FDI and technology upgrading or knowledge spillovers is quite numerous. A metareview of this literature by Bruno and Campos (2013) shows that the effect of FDI on economic performance and growth are conditional. Firms, sectors or countries that are below certain "thresholds" (either regarding human capital, financial development or institutional quality) are less likely to benefit from FDI. Overall, benefits are significantly greater in low-income than in lower and upper middle-income countries (both at the micro and macro level). Available data provide stronger support for differentiating the effect of FDI on growth across levels of development rather than regarding geographic regions.

The effects at the macro level depend on upon whether recipient countries have attained minimum levels of human capital, financial and institutional development. The effects of FDI using firm-level data tend to find that the (micro-) effect is conditional on the type of linkages (with backwards linkages, that is, links between the firm and its suppliers, dominating over horizontal or forward linkages).

Indeed, FDI is a potential source of technology upgrading. Integration into the global economy and FDI can act as important catalysts for change, but equally, FDI alone are not the driver of technology upgrading. As literature suggests, their effects on upgrading are highly differentiated and dependent on indigenous technology effort. Even when countries are integrated globally in R\&D networks, they do not necessarily link up with domestic manufacturing value chain which leads to what Ernst (2014) describes using the example of Indian electronics as 'truncation of FDI based learning'. 
FDI indicators are of limited value in detecting the true knowledge that is acquired through international industrial networks. Research on global value chains (GVC) is useful in that respect though it is hard to generalise. Different contributions show the positive and significant effects of learning through value chains on the process, product and functional upgrading up to ODM level. Yoruk (2013) shows the major importance of both knowledge and production networks for firms' upgrading but also that it is highly misleading to narrowing learning opportunities for upgrading to interactions with the global buyers within GVCs. Her research in the case of Eastern Europe shows that learning by doing and learning by exporting do not have statistically significant effect on functional upgrading. She reveals that opportunities offered by GVCs will be of little use unless firms have the ability to internalise this external knowledge through its human resources, through training and research within the enterprise. She also shows that managerial upgrading is essential to technology upgrading, but global buyers do not support it. This result again highlights the importance of organisational capabilities or firms' structure that we discussed under the structural dimension of technology upgrading.

The literature suggests that this axis of technology upgrading is not similar to the former two. Namely, the intensity of technology upgrading axis assumes that the higher the countries' ranking in specific sub-components and individual indicators, the higher the potential of the economy for technology upgrading and thus for long-term growth. The more developed the production, technology and R\&D capabilities, the higher the possibility of technology-based growth of the economy. Also, the more countries are diversified regarding structural features of technology upgrading; the higher is their potential for technology upgrading. However, the relationship between upgrading and structural change is non-linear, i.e. it changes at different levels of development. Also, technology and knowledge exchange is a complementary factor, i.e. higher inflows of knowledge and technology do not lead to higher technology upgrading as its ultimate effects will depend on interaction with other two components.

\subsubsection{TECHNOLOGY AND KNOWLEDGE EXCHANGE}

Out of the three dimensions of technology upgrading, the interaction with global economy dimension is probably the most difficult to capture, since technology transfer happens through capital equipment import, it is embedded in modes of FDI, networks and subcontracting or is disembodied (licences). So, modes of transfer by themselves cannot be taken as proxies of the real knowledge transfer that has taken place (Radosevic, 1999). Given that complexity, we consider the distinction between knowledge imports and exports via licences, FDI outflows and inflows and share 
of exports in complex industries. We intentionally take this very broad category of complex industries which includes SITCRev3 categories 5, 71-79, 87 and 88 to avoid the problem of narrow definitions of high technology, which ignores value added difference. We assume that export in these industries is on average of somewhat higher complexity than in other industry groups.

However, the higher share of complex industries in exports may not indicate export of technological knowledge in whatever form as countries may be integrated through vertical specialisation but at low value added segments. Also, FDI can bring knowledge and generate spillovers, but equally, it may lead to small or negative spillovers. Technology Balance of payment is an outcome of transfer pricing, and thus its positive or negative balance may often be unrelated to real flow of knowledge.

\section{DATA AND METHODOLOGY}

Technological upgrading is a flow rather than a stock concept. Hence, the major challenge is to find series that are long enough to depict the changing levels of technological activities and capabilities. Unfortunately, there is not sufficiently long data series, which would enable us to construct longterm series of technology upgrading which could be regarded as flows. Instead, we are forced to measure technology upgrading index only regarding levels or stock. Luckily, unlike macroeconomic variables technological capabilities are changing very slowly even during periods of deep economic crises or high growth periods (Archibugi et al., 2009).

\subsection{DATA}

Data for individual indicators (Tables 1, 2 and 3) have been acquired from a variety of sources: World Bank, WEF Global Competitiveness Report, WIPO, UNESCO, UNComtrade, ISO, Thomson NSI, Forbes and Barro-Lee dataset at national level for 42 countries (see Appendix A for a list of selected countries). Relevance to the analysis, availability and comparability were the criteria used to select the indicators. These criteria have also determined the use of a mixture of 'hard' and 'subjective' indicators. Missing data accounted for less than $5 \%$ of the data. Missing values in the data set have been treated using several methods. Where possible, missing values were replaced with values from an external source, e.g. from a previous round of the same survey. ${ }^{8}$ The remaining missing values were treated by multiple imputation methods. ${ }^{9}$ Afterwards, the data are classified into three broad

\footnotetext{
${ }^{8}$ Missing data for Belarus mostly comprised of WEFGCR indicators. Belarus has themselves conducted this survey asking the same questions to domestic firms. Therefore, we used their data to complement missing data in our database.

${ }^{9}$ Multiple imputation (MI) is a general approach that does not require a specification of parameterised likelihood for all data. The imputation of missing data is performed with a random process that reflects uncertainty. Imputation is done N times, to create N "complete" datasets. We have used Markov Chain Monte
} 
indexes as represented in the analytical framework (see Radosevic and Yoruk, 2016a and Tables 1, 2 and 3).

Table 1. Components and indicators of Technology Upgrading Intensity Index (Index A).

\begin{tabular}{|c|c|c|c|c|c|c|}
\hline $\begin{array}{l}\text { Index } \\
\text { A }\end{array}$ & Component & Quantitative Indicators & Source & Year & $\begin{array}{l}\text { Comp } \\
\text { weight }\end{array}$ & $\begin{array}{l}\text { Cronbach's } \\
\text { alpha }\end{array}$ \\
\hline \multirow{3}{*}{ 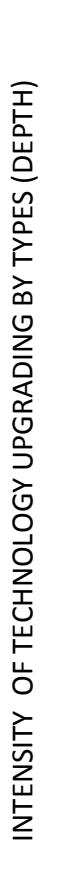 } & $\begin{array}{l}\text { Production } \\
\text { capability } \\
\text { (Index } 1)\end{array}$ & $\begin{array}{l}\text { 1.ISO9001 certificates pmi } \\
\text { 2.Trademark applications, resident pmi } \\
\text { 3.On the job training Q.5.C }\end{array}$ & $\begin{array}{l}\text { ISO } \\
\text { WB } \\
\text { WEFGCR }\end{array}$ & $\begin{array}{l}2007-11 \\
\text { Avg } \\
2012-13\end{array}$ & $1 / 3$ & \multirow[b]{3}{*}{0.946} \\
\hline & $\begin{array}{l}\text { Technology } \\
\text { capability } \\
\text { (Index 2) }\end{array}$ & $\begin{array}{l}\text { 4.Patents resident applications to national } \\
\text { office pmi } \\
\text { 5.Patent applications to USPTO pmi } \\
\text { 6.Patent applications to EPO pmi } \\
\text { 7.Resident's industrial design count pmi }\end{array}$ & $\begin{array}{l}\text { WB } \\
\text { WIPO } \\
\text { WIPO } \\
\text { WIPO }\end{array}$ & $\begin{array}{l}2007-11 \\
\text { Avg }\end{array}$ & $1 / 3$ & \\
\hline & $\begin{array}{l}\text { R\&D and } \\
\text { knowledge } \\
\text { intensity } \\
\text { (Index 3) }\end{array}$ & $\begin{array}{l}\text { 8.Business Enterprise Sector R\&D } \\
\text { expenditures (\% of GDP) } \\
\text { 9.Research and development expenditure (\% } \\
\text { of GDP) } \\
\text { 10.Researchers in R\&D pmi } \\
\text { 11.Technicians in R\&D pmi } \\
\text { 12.Scientific and technical journal articles } \\
\text { pmi } \\
\text { 13.Science citations pmi } \\
\text { 14.The quality of scientific research } \\
\text { institutions Q.12.02 } \\
\text { 15.University - industry collaboration in R\&D } \\
\text { Q.12.04 }\end{array}$ & $\begin{array}{l}\text { ThomsonNSI } \\
\text { WEFGCR }\end{array}$ & $\begin{array}{l}2007-11 \\
\text { Avg } \\
2012-13\end{array}$ & $1 / 3$ & \\
\hline
\end{tabular}

Table 2. Components and indicators of Technology Upgrading Breadth Index (Index B).

\begin{tabular}{|c|c|c|c|c|c|c|}
\hline $\begin{array}{l}\text { Index } \\
\text { B }\end{array}$ & Component & Quantitative Indicators & Source & Year & $\begin{array}{l}\text { Comp } \\
\text { weight }\end{array}$ & $\begin{array}{l}\text { Cronbach's } \\
\text { alpha }\end{array}$ \\
\hline 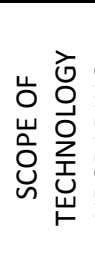 & $\begin{array}{l}\text { Infrastructure: } \\
\text { human capital } \\
\text { and physical } \\
\quad \text { and } \\
\text { organisational } \\
\quad \text { (Index 4) }\end{array}$ & $\begin{array}{l}\text { 1.Average years of schooling } 25+ \\
\text { 2.Quality of maths and science education } \\
\text { Q.5.04 } \\
\text { 3.Availability of research and training services } \\
\text { Q.5.07 } \\
\text { 4.Availability of scientists and engineers } \\
\text { Q.12.06 }\end{array}$ & $\begin{array}{l}\text { Barro- } \\
\text { Lee } \\
\text { WEFGCR }\end{array}$ & $\begin{array}{l}2010 \\
2012-13 \\
2012\end{array}$ & $1 / 3$ & 0.893 \\
\hline
\end{tabular}

Carlo (MCMC) method. MCMC is a sequence of random variables in which the distribution of the actual element depends on the value of the previous one. It assumes that data are drawn from a multivariate normal distribution and requires assumptions that missing values are missing at random. The theory of MCMC is most easily understood using Bayesian methodology (OECD, 2008). 


\begin{tabular}{|c|c|c|c|c|}
\hline & $\begin{array}{l}\text { 5.Fixed broadband Internet subscribers (per } \\
100 \text { people) } \\
\text { 6.Gross Fixed Investment as \% of GDP }\end{array}$ & WB & & \\
\hline $\begin{array}{l}\text { Structural } \\
\text { change } \\
\text { (Index 5) }\end{array}$ & $\begin{array}{l}\text { 7.Herfindahl-Hirschman Index for total } \\
\text { national patent applications } \\
\text { 8.Herfindahl-Hirschman Index for patent } \\
\text { applications to EPO } \\
\text { 9.Herfindahl-Hirschman Index for patent } \\
\text { applications to USPTO } \\
\text { 10.Buyer sophistication Q.6.16 } \\
\text { 11.Change in buyer sophistication( \% change } \\
\text { in Q. } 6.16 \text { from } 2006-07 \text { to } 2012-13 \text { ) } \\
\text { 12.Availability of state-of-the-art technologies } \\
\text { Q.9.01 } \\
\text { 13.Change in availability of latest } \\
\text { technologies( \% change in } 9.01 \text { from } 2006-07 \\
\text { to } 2012-13 \text { ) }\end{array}$ & WEFGCR & $\begin{array}{l}\text { 2007-12 } \\
\text { avg } \\
\text { 2012-13 }\end{array}$ & $1 / 3$ \\
\hline $\begin{array}{l}\text { Firm-level } \\
\text { capabilities } \\
\text { (Index 6) }\end{array}$ & $\begin{array}{l}\text { 14.Number of enterprises in Forbes } 2000 \mathrm{pmi} \\
\text { 15.Firm-level technology absorption } \mathrm{Q} .9 .02\end{array}$ & $\begin{array}{l}\text { Forbes } \\
\text { WEFGCR }\end{array}$ & $\begin{array}{l}2013 \\
2012-13\end{array}$ & $1 / 3$ \\
\hline
\end{tabular}

Table 3. Indicators of Technology and Knowledge Exchange Index (Index C)

\begin{tabular}{|c|c|c|c|c|}
\hline Index C & Quantitative Indicators & Source & Year & $\begin{array}{l}\text { Cronbach } \\
\text { is alpha }\end{array}$ \\
\hline $\begin{array}{l}\text { INTERACTION } \\
\text { WITH GLOBAL } \\
\text { ECONOMY } \\
\text { (TECHNOLOGY } \\
\text { AND KNOWLEDGE } \\
\text { EXCHANGE) }\end{array}$ & $\begin{array}{l}\text { 1.Licensing receipts as \% of GDP } \\
\text { 2.Licensing payments as \% of GDP } \\
\text { 3.Share of exports in complex industries in total } \\
\text { exports (SITCRev3 } 571-7987 \text { 88) } \\
\text { 4.Foreign direct investment, net outflows (\% of GDP) } \\
\text { 5.Foreign direct investment, net inflows (\% of GDP) }\end{array}$ & $\begin{array}{l}\text { WB } \\
\text { UNComtrade } \\
\text { WB }\end{array}$ & $\begin{array}{l}2012 \\
2008-12 \\
\text { Avg } \\
2007-12 \\
\text { Avg }\end{array}$ & 0.827 \\
\hline
\end{tabular}

\subsection{DEVELOPING MEASURES BY COMPOSITE INDEX METHODOLOGY}

The individual indicators in Tables 1, 2 and 3 have then been used to construct latent variables for the three indexes Index A, Index B and Index C by using composite index methodology. ${ }^{10}$

A typical composite indicator will take the form (Freudenberg, 2003: 7):

$$
I=\sum_{i=1}^{n} w_{i} \mathrm{X}_{i}
$$

where

I: Composite index,

$\mathrm{X}_{i}$ : Normalised variable,

\footnotetext{
${ }^{10}$ Composite indexes are widely used in economic and business statistics for benchmarking the relative progress of countries in a variety of policy domains such as competitiveness, globalization and innovation. Even though Grupp and Mogee (2004) criticize the approach for its vulnerability to manipulation, Archibugi et al. (2009) stress that when they are used in the right perspective and within a sound theoretical framework they can be extremely useful tools. For instance see Radosevic and Yoruk (2011) on formation of composite indexes from entrepreneurship perspective.
} 
Wi: $_{i}$ Weight of the $X_{i}$

$\sum_{i=1}^{n} w_{i}=1$ and $0 \leq w \leq 1$

$i: 1, \ldots, \mathrm{n}$.

Equation (2) shows explicitly the normalisation method (Min-Max) used:

(2) $I_{c}=\sum_{j=1}^{J} \sum_{m=1}^{M} w_{j m}\left\{\left(\mathrm{X}_{j m c}-\mathrm{X}_{j m}^{\min }\right) \mid\left(\mathrm{X}_{j m}^{\max }-\mathrm{X}_{j m}^{\min }\right)\right\}$

where $\mathrm{c}$ indicates country, $\mathrm{j}$ and $\mathrm{m}$ are indicator and component subscripts and min and max denote the minimum and maximum values of each indicator across countries.

Based on our analytical framework, the first index (intensity of technology upgrading) consists of three components: production capability, technology capability and R\&D and knowledge intensity based on sixteen indicators. The index of the breadth of technology upgrading also contains three components: human capital and physical infrastructure, structural change and firm-level capabilities based on thirteen indicators. Index C covers five manifest indicators representing knowledge inflow and outflow from a country. ${ }^{11}$ The sources, availability and weights for each of these indexes and their indicators are presented in Tables 1, 2 and 3. All indexes are estimated based on the normalisation ${ }^{12}$ of indicators followed by aggregation ${ }^{13}$ of components with equal weights given to each element. In the existing literature, there are numerous weighting methods with pros and cons. These vary from equal weighting to use for statistical models such as factor analysis (FA)/principal component analysis (PCA), or a 'benefit of the doubt' (BOD) approach which is sensitive to national priorities and weights are country specific (OECD, 2008: 32). Based on our already developed analytical framework, we use an equal weighting method applied on each component. OECD (2008:31) states that "most composite indicators rely on equal weighting, i.e. all variables have the same weight. This criterion essentially implies that all variables are 'worth' the same in the composite, but it could also disguise the absence of a statistical or empirical basis, e.g. when there is insufficient knowledge of causal relationships or a lack of consensus on the alternative. Moreover, if variables are grouped into components and those are further aggregated into the composite, then

\footnotetext{
${ }^{11}$ See Appendix $B$ for a detailed explanation of indicators and the formation of indexes.

${ }^{12}$ We have used Min-Max (distance from the best and worst performers) normalization method in this research, since this is the most compatible method with the indicators we have chosen.

${ }^{13}$ Linear, geometric or multi-criteria aggregation might be applied. We opted for linear aggregation method where substitution along dimensions (components) is constant, which we prefer in accordance with our conceptual framework. It is also compatible with Min-Max method of normalization, especially when individual indicators are measured in different units. Technical weaknesses of the aggregation convention are widely discussed in Munda and Nardo (2009).
} 
applying an equal weighting to the variables may imply an unequal weighting of the component (the components grouping the larger number of variables will have higher weight). This could result in an unbalanced structure in the composite index." That is why we have given the same weight to each component as based on our analytical framework and then determined the weight of each indicator to achieve a balanced structure in the composite index.

We also provide Cronbach's alpha coefficient of reliability for each of the latent constructs (see Tables 1, 2 and 3) to further indicate the correlation between the selected indicators (Anderson and Gerbing, 1988). C-alpha in each case is above the 0.70 thresholds of acceptable reliability (Nunnally, 1978). So, they are highly likely to share common factors as outlined by our analytical framework and it is evidence that the indicators are measuring the same underlying construct (OECD, 2008: 712). We also provide the results of Confirmatory Factor Analysis (CFA) applied to indicators for each component separately in Appendix C. The indicators selected for the components and main indices merge into factor groups assuring the validity of the constructs.

In Appendix C, we also show how well individual components of indexes covariate between itempairs, i.e. how well they are loading on the common factor. For six indexes (except production capability) index we have very high C-alpha scores. Production capability index which consists of ISO9001 certificates, trademark applications per million of the population and subjective assessment of the on the job training has a low-reliability score of 0.458 . We think that this reflects much less conceptual inconsistency of production capability concept but more diversity of investments in this capacity at countries of different income levels.

\section{ANALYSIS OF LEVELS AND PROFILES OF TECHNOLOGY UPGRADING}

Data that form the basis for this research enable quite detailed exploration of the relationship between specific income groups and reveal very relevant comparative insights on different economies. Much of these are discussed in our working paper (see Radosevic and Yoruk, 2016b) which form the basis for this article. In this article, mainly due to space reasons we confine the analysis on broad relationships between income levels and indexes of technology upgrading, with particular reference to middle-income economies. 


\subsection{PROBING THE RELATIONSHIPS BETWEEN ASPECTS OF TECHNOLOGY UPGRADING AND DIFFERENT INCOME LEVELS}

We first present results from the construction of three composite indexes underlying major aspects of technology upgrading for 42 selected middle and high-income economies categorised by income levels (Table 4). A multidimensional approach to analysis gives us the opportunity to explore profiles of technology upgrading and their relationships to income levels.

Indexes of technology upgrading do not indicate speed or pace of upgrading as that would require long time series which are simply not available for the type indicators that are necessary for measuring technology upgrading. However, an index represents proxy of potential for technology upgrading. In that respect, a country that ranks low regarding income per capita but has high magnitude of indexes of technology upgrading suggest that it has real potential for growth based on technology upgrading.

Table 4.The three indexes of technology upgrading by income group and country.

\begin{tabular}{|c|c|c|c|c|c|c|}
\hline Income Group & Country & $\begin{array}{l}\text { INDEX A: INTENSITY } \\
\text { OF TECHNOLOGY } \\
\text { UPGRADING }\end{array}$ & Country & $\begin{array}{l}\text { INDEX B: BREADTH } \\
\text { OF TECHNOLOGY } \\
\text { UPGRADING }\end{array}$ & Country & $\begin{array}{l}\text { INDEX C: INDEX OF } \\
\text { INTERACTION WITH } \\
\text { GLOBAL ECONOMY }\end{array}$ \\
\hline \multirow{3}{*}{ 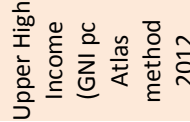 } & Sweden & 63.4 & Sweden & 77.1 & Ireland & 100.0 \\
\hline & Germany & 58.7 & Japan & 73.2 & Belgium & 57.1 \\
\hline & Japan & 57.5 & Ireland & 69.8 & UHI AVERAGE & 37.7 \\
\hline
\end{tabular}




\begin{tabular}{|c|c|c|c|c|c|c|}
\hline & Belgium & 52.0 & United States & 68.2 & Sweden & 36.0 \\
\hline & Austria & 51.1 & Belgium & 65.9 & United Kingdom & 29.1 \\
\hline & UHI AVERAGE & 49.7 & UHI AVERAGE & 65.8 & Austria & 27.5 \\
\hline & United States & 48.8 & United Kingdom & 65.6 & United States & 24.7 \\
\hline & United Kingdom & 44.1 & Austria & 64.6 & Japan & 24.4 \\
\hline & Ireland & 36.1 & Germany & 62.8 & Germany & 23.5 \\
\hline & Italy & 35.3 & Italy & 44.6 & Italy & 17.1 \\
\hline \multirow{11}{*}{ 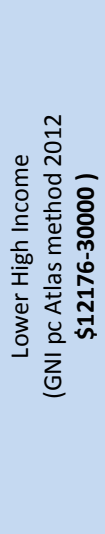 } & Korea, Rep. & 66.6 & Korea, Rep. & 67.5 & Estonia & 25.0 \\
\hline & Slovenia & 35.5 & Portugal & 53.6 & Korea, Rep. & 22.3 \\
\hline & Spain & 34.5 & Spain & 51.6 & Spain & 21.7 \\
\hline & Czech Republic & 33.9 & Estonia & 50.0 & Slovenia & 20.4 \\
\hline & Portugal & 31.4 & Chile & 49.3 & Czech Republic & 19.6 \\
\hline & Estonia & 30.1 & LHI AVERAGE & 48.4 & Chile & 18.5 \\
\hline & LHI AVERAGE & 30.0 & Czech Republic & 47.7 & LHI AVERAGE & 18.0 \\
\hline & Chile & 21.8 & Greece & 46.5 & Portugal & 17.3 \\
\hline & Poland & 17.7 & Slovenia & 42.9 & Poland & 17.1 \\
\hline & Greece & 15.2 & Poland & 40.0 & Russian Federation & 11.1 \\
\hline & Russian Federation & 13.9 & Russian Federation & 34.4 & Greece & 7.1 \\
\hline \multirow{16}{*}{ 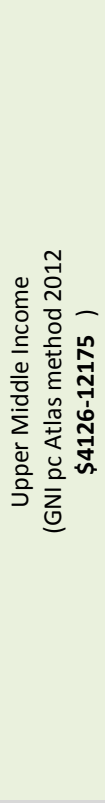 } & Malaysia & 23.1 & Malaysia & 55.8 & Hungary & 62.6 \\
\hline & China & 21.8 & China & 47.9 & Jordan & 25.0 \\
\hline & Hungary & 21.3 & Jordan & 45.1 & Bulgaria & 21.2 \\
\hline & Turkey & 18.3 & South Africa & 42.8 & Malaysia & 20.4 \\
\hline & Brazil & 17.9 & Mexico & 42.2 & China & 19.0 \\
\hline & South Africa & 15.4 & Turkey & 42.2 & UMI AVERAGE & 18.7 \\
\hline & Bulgaria & 14.7 & Brazil & 42.1 & Thailand & 17.9 \\
\hline & UMI AVERAGE & 14.2 & Hungary & 42.0 & Mexico & 17.7 \\
\hline & Mexico & 12.9 & Thailand & 41.9 & Turkey & 15.8 \\
\hline & Jordan & 12.1 & UMI AVERAGE & 38.7 & Kazakhstan & 15.0 \\
\hline & Peru & 11.6 & Kazakhstan & 35.1 & Romania & 13.9 \\
\hline & Romania & 11.4 & Romania & 33.3 & Albania & 13.1 \\
\hline & Thailand & 11.4 & Bulgaria & 32.7 & Belarus & 12.6 \\
\hline & Kazakhstan & 8.4 & Peru & 30.8 & Brazil & 9.8 \\
\hline & Belarus & 6.5 & Albania & 29.2 & South Africa & 9.5 \\
\hline & Albania & 6.4 & Belarus & 17.7 & Peru & 6.9 \\
\hline \multirow{9}{*}{ 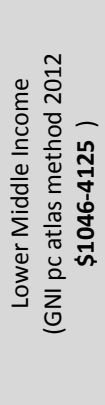 } & Indonesia & 10.9 & Ukraine & 44.1 & Vietnam & 18.2 \\
\hline & India & 10.7 & Morocco & 40.7 & Ukraine & 12.5 \\
\hline & Ukraine & 10.1 & India & 39.9 & LMI AVERAGE & 10.9 \\
\hline & Philippines & 10.1 & Indonesia & 37.4 & Moldova & 10.7 \\
\hline & Morocco & 8.9 & Philippines & 36.6 & Philippines & 10.3 \\
\hline & LMI AVERAGE & 8.8 & LMI AVERAGE & 33.3 & India & 9.9 \\
\hline & Vietnam & 8.5 & Moldova & 25.3 & Morocco & 9.8 \\
\hline & Ghana & 6.0 & Vietnam & 21.5 & Ghana & 9.1 \\
\hline & Moldova & 5.1 & Ghana & 20.7 & Indonesia & 6.4 \\
\hline
\end{tabular}

The highest ranking countries regarding index of intensity of technology upgrading are Korea,

Sweden, Germany and Japan. Korea has very high index given its current level of income and thus has excellent potential for further growth based on technology. Given its level of income, Italy has the modest potential for further technology upgrading. Similarly, Russia has very low potential for 
technology-based growth given its income level. Although Poland has been a fast-growing Central and Eastern European (CEE) economy in the last 20 years, it seems that its potential for technologybased growth does not look so bright. Of course, Poland may grow based on its production capability, and on-non-technological factors for some time but it seems that drivers for technologybased growth are far from where they should be given its recent high growth. China's ranking regarding the intensity of technology upgrading is well above its income per capita, which suggests room for further growth based on technology. However, we should bear in mind that the majority of indicators are used on per capita basis, which clearly underestimate differences in the absolute size of economies and nonlinear effects that this may generate. For instance, the issue of absolute vs. relative size is striking when comparing India and Ukraine with their respective gross national income per capita (GNI pc) of $\$ 1550$ and $\$ 3640$, but with Ukraine and India being comparable regarding the index of technology upgrading intensity even though the majority of indicators are used in per capita terms.

There are much larger differences in ranking among countries relating to the intensity of technology upgrading than regarding the technology upgrading breadth index capturing structural change (Fig.1 and Table 4). The ordering of countries within specific income groups is much more regular, i.e. related to income per capita for the intensity of technology upgrading than for the breadth of upgrading. This is especially the case from upper middle-income group upwards and less for the lower middle-income group. This may be expected as technology, and its cumulative features play a much more important role in income generation the nearer is the country to the technology frontier. Additionally, a much stronger convergence regarding the breadth of or scope of technology upgrading is due to smaller differences in infrastructure but especially due to the intensive process of structural change, which takes place at different levels of different income groups. So, much of these differences regarding the breadth of technology upgrading are mainly due to remain third component - differences regarding firm-level organisational capabilities. It is on firm level organisation capabilities that we have on average the biggest differences within (not between) different income groups (Figure 2).

The third component of technology upgrading is the interaction with the global economy or technology and knowledge exchange (Table 4 and Fig 1). The link between income levels and the index of technology and knowledge exchange is much different from those of the indexes of intensity and breadth of technology upgrading. This link is quite weak, both overall and within four income groups and with three major outliers (Ireland, Hungary and Belgium). These outliers are mainly due to the high share of FDI, both in inflows and outflows, and a large proportion of 
technology balance of payments and receipts, which reflect transfer pricing related to high levels of FDI. Still, even if we ignore the outliers the index of technology and knowledge exchange is on average related to income levels of income groups but not within groups. The fourth outlier is Greece, despite being the lower high-income economy in the $40^{\text {th }}$ place regarding the index of technology and knowledge exchange in the sample of 42 economies. This is due in large part to the very low share of inward FDI and related to that a low proportion of technology payments in GDP.

Figure 1 shows the relationship between average scores for four income groups of countries across three indexes (intensity and breadth of technology upgrading indexes and the index of interaction with global economy). As expected, income groups are ordered in decreasing manner across all three indexes. However, the range of income groups is the biggest in the case of the index of intensity of technology upgrading ( 82 percentage points between low, middle income and upper high income) and smallest in the case of the index of the breadth of technology upgrading (49 percentage points). The global interaction index is close to the index of intensity of technology upgrading (71 percentage points). These results suggest that breadth of technology upgrading is much more present at lower income levels while the intensity of technology upgrading is significantly less intensive in the lower income groups. Also, technology and knowledge exchange are considerably more intensive in the case of the upper high-income group, but it is much more compressed in the case of lower high income and upper middle-income groups.

Figure 1. Indexes of intensity and breadth of technology upgrading and interaction with global economy by income groups.

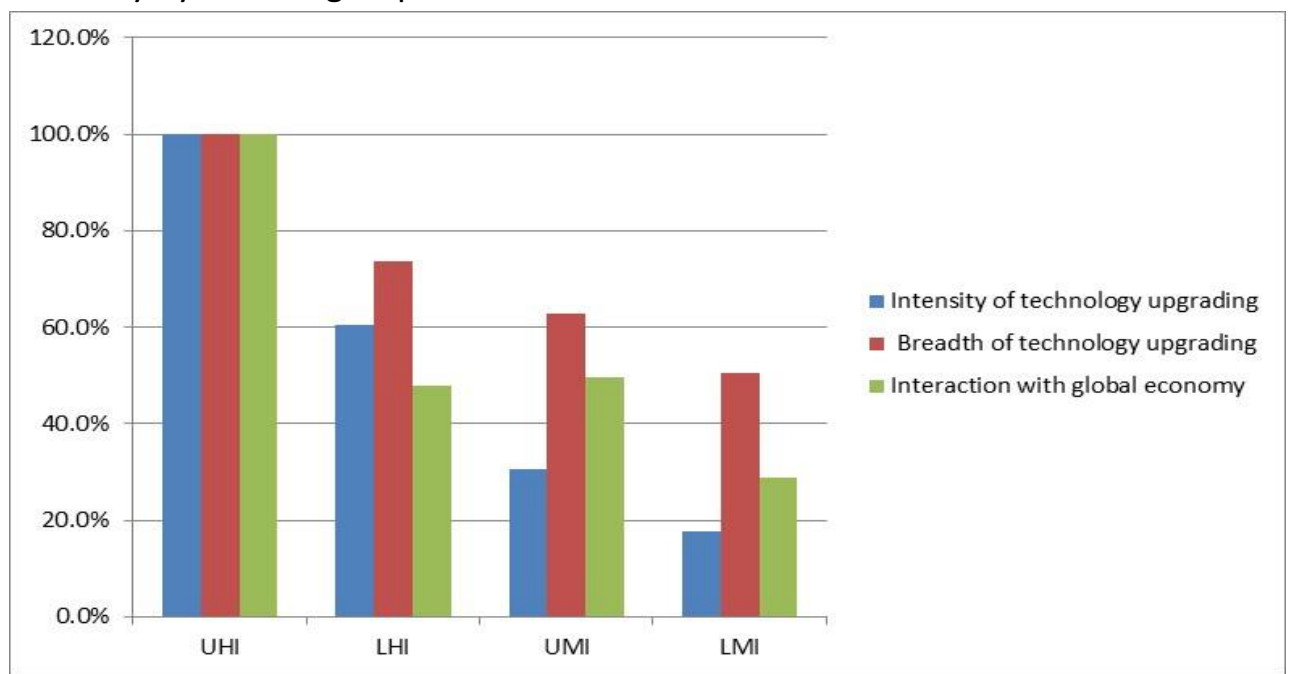

Figure 2 shows six sub-indexes. Again, each of the sub-indexes is ranked in decreasing order as average income per capita of the groups fall. The biggest range is in the case of technology capability, where the difference between upper high income and lower middle-income groups is $96 \%$ percentage points. The gap between upper high income and middle-income economies is 
strikingly elevated in this case, which suggests that generation of frontier technology is the domain of only the highest income bracket group. Production and R\&D capabilities are also quite dispersed with 77 and 79 percentage points' difference. In the case of production capability, their ranking is quite ordered with similar distances between different income groups. However, it is less orderly for R\&D capability, where the middle-income group is relatively less advanced than regarding their production capability. The breadth of technology upgrading is much less dispersed with a max-min difference for structural change being only 32 percentage points and for infrastructure 48 percentage points. These data suggest that structural change may be of different types, but it does take place at various income levels creating a quite compressed distribution with small differences between the different income groups. Differences in infrastructure are comparatively lower, but the difference between two middle-income groups are quite small but significant when compared to the upper high-income group. Firm-level organisation capabilities are closer to the dispersion of production and R\&D capability (69 percentage points). However, they are distinctively less developed in the case of lower high income and middle-income economies when compared to the upper top income group. They are not as pronounced as in the case of technology capabilities, but they are concentrated much more on upper high income than in the lower high-income group. So, the threshold level for firm organisational capabilities is located much higher regarding income than for infrastructure, R\&D or production capabilities.

Figure 2. Sub-indexes of technology upgrading by income groups.

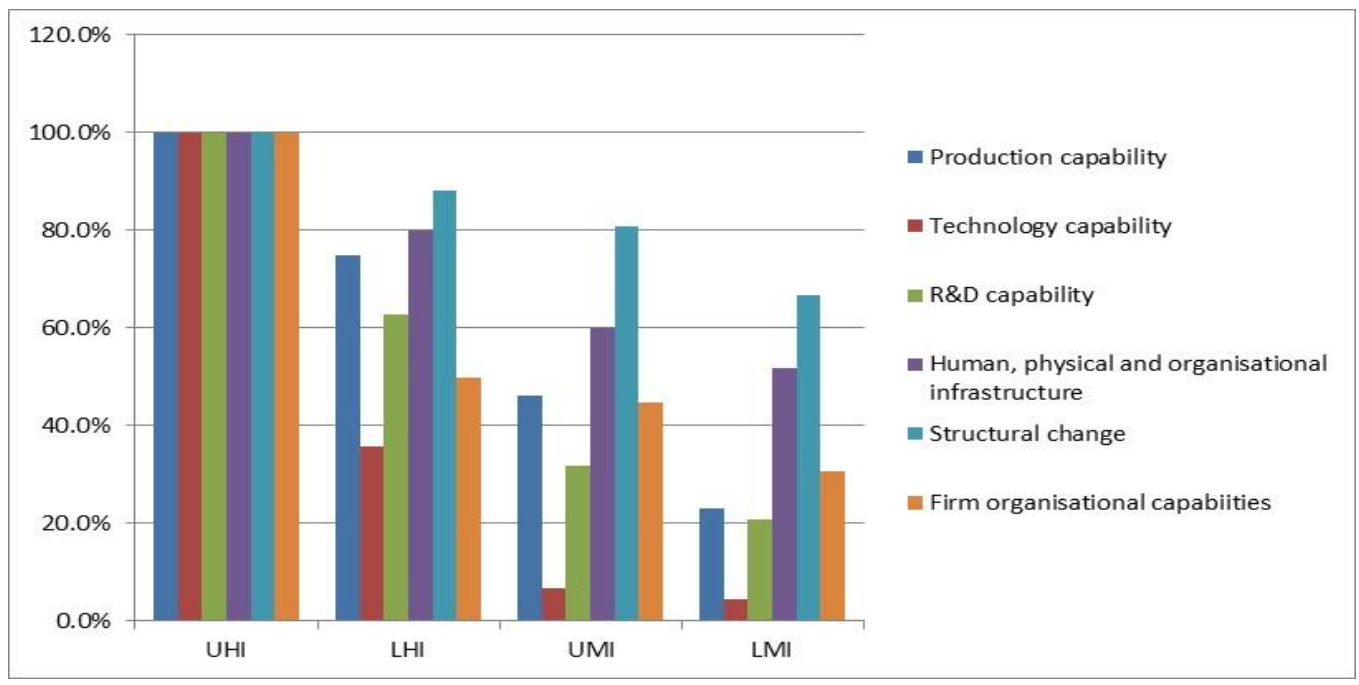

Before moving onto the next section, we remind that the primary value of our contribution is not in the ranking of economies but a better understanding of patterns of technology upgrading. As we pointed out earlier, the correlation between our three indexes and other similar composite indicators based rankings shows a relatively high degree of correlation (Table 5). 
Table 5. Rank correlation of selected indexes.

\begin{tabular}{|c|c|c|c|}
\hline & $\begin{array}{c}\text { Index A } \\
\text { (intensity) } \\
\end{array}$ & $\begin{array}{c}\text { Index B } \\
\text { (breadth) }\end{array}$ & $\begin{array}{c}\text { Index C } \\
\text { (interaction) }\end{array}$ \\
\hline Index A (intensity) (2007-2013) & 1 & & \\
\hline Index B (breadth) (2007-2013) & 0.889 & 1 & \\
\hline Index C (interaction) (2007-2013) & 0.7293 & 0.7009 & 1 \\
\hline WEF GCR Technological Readiness index (2015-16) & 0.8683 & 0.7915 & 0.7017 \\
\hline WEF GCR Technological Readiness index (2010-11) & 0.9066 & 0.8075 & 0.8082 \\
\hline WEF GCR Technological Innovation Index (2015-16) & 0.8174 & 0.8608 & 0.6669 \\
\hline WEF GCR Technological Innovation Index (2010-11) & 0.8538 & 0.8383 & 0.6585 \\
\hline INSEAD Global innovation Index (2014) & 0.9030 & 0.8202 & 0.7943 \\
\hline UNIDO Competitive Industrial Performance Index (2012) & 0.8224 & 0.7800 & 0.6898 \\
\hline World Bank Knowledge Economy Index (2012) & 0.8741 & 0.7851 & 0.7509 \\
\hline Technological Capabilities Index ArCo (2000) & 0.8355 & 0.7366 & 0.6672 \\
\hline
\end{tabular}

Note: Number of countries for all indexes is 41 out of 42 except Belarus. All correlations are statistically significant at the level of 0.0000 .

However, we also note that the degree of correlation decreases from the index of intensity of upgrading to the index of interaction with the global economy. The average correlation coefficients between indexes $A, B$ and $C$ and other indexes are $0.86,0.80$ and 0.72 respectively. This further confirms that the knowledge interaction with the global economy is not linearly related to technology upgrading as foreign inflows may operate either as a substitute or as complementary to endogenous technology upgrading.

\subsection{IS THERE MIDDLE-INCOME TRAP?}

In continuation, through a series of OLS regressions we test the econometric robustness of the relationship between indexes and income levels. However, we add a dummy variable for different income groups so that we can detect what visually seems present - technology related middleincome trap phenomenon. From technology point of view, we define it as the inability of economies to accumulate technology capabilities and rate of innovation which would enable them to achieve high-income status.

Model 1 (Table 6) shows results of a regression of index of technology upgrading intensity on income levels with separate dummies for each of four income groups. We are interested whether dummies are statistically significant. If dummies are negative, that would indicate the presence of income trap for that particular group or some unspecified reason that the level of the index for that group is not corresponding to the income level for the whole sample. If positive, it would indicate the groupspecific factor, which makes the income level to be higher than expected given the technology upgrading level of the group. Results confirm what we could visually observe. First, dummy for the 
aggregate middle-income group is significantly negative suggesting the existence of technology middle income trap. Dummy for the upper high-income group is also significant but positive suggesting a kind of top high-income bonus or level of income which does not reflect the degree of technology upgrading as captured by our index. ${ }^{14}$ This may be expected, as our index is aimed to measure progression from middle income to high income rather than explain differences among the high-income economies. Dummy variables for middle-income subgroups are negative but not significant, which suggest that the middle-income phenomenon is not easily detectable and is spread across several components of the index of technology upgrading intensity. Also, dummy for the lower high-income group is negative, but not significant suggesting that the phenomenon of the middle-income trap may also be much more dispersed across income groups and should not necessarily correspond to middle-income groups as defined in this paper. However, the inclusion of dummies in OLS shows that technology upgrading is closely correlated to income levels as R-squared is very high. ${ }^{15}$ It is the highest in regression with the upper high-income group, which may be expected given the increasing role that technology plays in growth as countries incomes rise.

OLS regressions with the index of the breadth of technology upgrading (Model 2) present more or less similar story as the Model 1 regressions. However, in Model 2.5 the dummy for upper highincome group turns out to be negative and statistically significant suggesting a bottleneck for this group regarding structural change issues. Dummy for upper middle-income subgroup show that both upper middle-income groups have statistically significant and negative dummies, which may indicate that the middle-income trap on structural change is more of an issue in the upper middleincome group than in the lower middle-income group.

OLS regression with the index of technology and knowledge exchange (Model 3) carries much less explanatory power as R-squared drops to much lower levels. However, in all models coefficient on the index is significant and dummies for aggregate middle income and upper high income are as in the previous model. Dummy for the middle-income group is negative suggesting that the levels of technology and knowledge exchange for this group are lower than would have been expected given the relationship. Also, dummy for the upper high-income group is positive suggesting that the level

\footnotetext{
${ }^{14}$ In Model 1 dummies are used in each sub model to understand the effect of income category on productivity (GNIpc). For instance, the coefficient for DuHI is 19259 which suggest that country in UHI category is expected to have USD19259 higher productivity than the country that belongs to any of the other income categories. Thus, being in the UHI group is not associated with technology upgrading trap but dividend. But, as we show throughout the OLS regressions in several models, being in other income categories is associated with technology driven income trap. This is largely statistically valid for MI group, hence it is called middleincome trap in technology upgrading.

${ }^{15}$ Results of regressions without dummies are presented in Appendix D.
} 
of knowledge exchange is greater than would have been expected given the relationship. Dummies for middle-income subgroups show that both upper and lower middle-income groups have statistically significant and negative dummies, which may indicate that the issue of the middleincome trap on technology and knowledge exchange is strongly present in both groups. Also, the coefficient for the dummy of the lower high-income group is positive but not significant. R-squared is much higher for the model with a middle-income dummy and with the upper high-income dummy, which again suggest that in the case of the middle-income group the gap regarding technology and knowledge exchange is quite significant. In other words, the issue of how these economies relate their technology upgrading activities to interaction with the global economy explains their lower than expected levels of income.

Table 7 shows OLS results for Index A: Intensity of technology upgrading, which is composed of three sub-indexes of production, technology and R\&D capability. Dummy for middle-income groups is significantly negative, and it is positive for the upper high-income group. Dummies for other subgroups are negative but not significant, except for Model 5.2. Signs for an index of production capability dummies are the same as for the Index of the intensity of technology upgrading except for dummy for an upper middle-income group where the coefficient is negative and significant at $10 \%$ level. This suggests that middle-income production capability trap is located within the middleincome group but more likely within the upper middle-income subgroup. In other words, given their production capability levels, this group records the level of income which is below expected. Regression with income and technology capability index shows negative and significant dummy coefficient for the aggregate middle-income group and lower middle-income group. So, the issue of 'technology capability middle-income trap' seems to be more relevant for the lower middle-income group. For lower high-income group, negative and 10\% level significant coefficient for production, capability becomes not significant but positive for technology capability. Regression for R\&D capability generates similar results as for production capability but with two important differences. First, the coefficient for the middle-income group is again negative but is significant only at $5 \%$ level suggesting that R\&D plays a major role in the absorptive capacity of middle-income economies. It explains why results for R\&D capability are more similar to production capability than to technology capability.

In Table 8, regression with Index B: Breadth of technology upgrading shows that dummy for the middle-income group is significant and negative. However, it is also significant and negative for the upper middle-income group (albeit except for index 4: human and physical infrastructure), which suggest that middle-income trap is more related to structural change issues in the subgroup of upper 
middle-income economies. This coefficient is positive and statistically significant only for the upper high-income group dummy, but not significant and negative for the lower upper high-income group. Index with infrastructure proxies also shows negative and significant dummy for the middle-income group but without a clear indication of the location of trap between two middle-income subgroups. The middle-income trap here is also largely located in the upper middle-income group. Finally, regression with the firm level organisation capabilities shows very strong middle income trap for both middle-income groups though much stronger in the upper middle-income group. Also, dummies for both high-income groups are positive but significant only for the upper high-income subgroup. 
Table 6. OLS regressions for Index A (intensity), Index B (breadth) and Index C (interaction).

\begin{tabular}{|c|c|c|c|c|c|c|c|c|c|c|c|c|c|c|c|}
\hline \multicolumn{16}{|c|}{ Dependent indicator: GNI per capita } \\
\hline & \multicolumn{5}{|c|}{ Model 1} & \multicolumn{5}{|c|}{ Model 2} & \multicolumn{5}{|c|}{ Model 3} \\
\hline & 1.1 & 1.2 & 1.3 & 1.4 & 1.5 & 2.1 & 2.2 & 2.3 & 2.4 & 2.5 & 3.1 & 3.2 & 3.3 & 3.4 & 3.5 \\
\hline Index A (intensity) & $\begin{array}{l}662 \\
(0.000)\end{array}$ & $\begin{array}{l}800 \\
(0.000)\end{array}$ & $\begin{array}{l}805 \\
(0.000)\end{array}$ & $\begin{array}{l}846 \\
(0.000)\end{array}$ & $\begin{array}{l}493 \\
(0.000)\end{array}$ & & & & & & & & & & \\
\hline Index B (breadth) & & & & & & $\begin{array}{l}638 \\
(0.000)\end{array}$ & $\begin{array}{l}884 \\
(0.000)\end{array}$ & $\begin{array}{l}877 \\
(0.000)\end{array}$ & $\begin{array}{l}944 \\
(0.000)\end{array}$ & $\begin{array}{l}471 \\
(0.000)\end{array}$ & & & & & \\
\hline Index C (interaction) & & & & & & & & & & & $\begin{array}{l}247 \\
(0.01)\end{array}$ & $\begin{array}{l}381 \\
(0.006)\end{array}$ & $\begin{array}{l}437 \\
(0.001)\end{array}$ & $\begin{array}{l}491 \\
(0.001)\end{array}$ & $\begin{array}{l}41 \\
(0.611)\end{array}$ \\
\hline Constant & $\begin{array}{l}5611 \\
(0.157)\end{array}$ & $\begin{array}{l}-1378 \\
(0.549)\end{array}$ & $\begin{array}{l}-1383 \\
(0.582)\end{array}$ & $\begin{array}{l}-2264 \\
(0.162)\end{array}$ & $\begin{array}{l}1423 \\
(0.294)\end{array}$ & $\begin{array}{l}-4443 \\
(0.483)\end{array}$ & $\begin{array}{l}-21858 \\
(0.000)\end{array}$ & $\begin{array}{l}-20553 \\
(0.000)\end{array}$ & $\begin{array}{l}-25408 \\
(0.000)\end{array}$ & $\begin{array}{l}23037 \\
(0.000)\end{array}$ & $\begin{array}{l}24901 \\
(0.000)\end{array}$ & $\begin{array}{l}12249 \\
(0.003)\end{array}$ & $\begin{array}{l}13199 \\
(0.001)\end{array}$ & $\begin{array}{l}6215 \\
(0.118)\end{array}$ & $\begin{array}{l}9449 \\
(0.000)\end{array}$ \\
\hline Dummy MI & $\begin{array}{l}-7716 \\
(0.021)\end{array}$ & & & & & $\begin{array}{r}-12999 \\
(0.000)\end{array}$ & & & & & $\begin{array}{l}-22796 \\
(0.000)\end{array}$ & & & & \\
\hline Dummy LMI & & $\begin{array}{l}-3181 \\
(0.304)\end{array}$ & & & & & $\begin{array}{l}-5100 \\
(0.180)\end{array}$ & & & & & $\begin{array}{l}-13917 \\
(0.016)\end{array}$ & & & \\
\hline Dummy UMI & & & $\begin{array}{l}-2092 \\
(0.412)\end{array}$ & & & & & $\begin{array}{l}-5431 \\
(0.071)\end{array}$ & & & & & $\begin{array}{l}-13399 \\
(0.003)\end{array}$ & & \\
\hline Dummy LHI & & & & $\begin{array}{l}-3629 \\
(0.162)\end{array}$ & & & & & $\begin{array}{l}-724 \\
(0.823)\end{array}$ & & & & & $\begin{array}{l}4475 \\
(0.397)\end{array}$ & \\
\hline Dummy UHI & & & & & $\begin{array}{l}19259 \\
(0.000)\end{array}$ & & & & & $\begin{array}{l}-8848 \\
(0.020)\end{array}$ & & & & & $\begin{array}{l}34133 \\
(0.000)\end{array}$ \\
\hline Number of observations & 42 & 42 & 42 & 42 & 42 & 42 & 42 & 42 & 42 & 42 & 42 & 42 & 42 & 42 & 42 \\
\hline F-test sig. & 0.000 & 0.000 & 0.000 & 0.000 & 0.000 & 0.000 & 0.000 & 0.000 & 0.000 & 0.000 & 0.000 & 0.000 & 0.000 & 0.000 & 0.000 \\
\hline $\mathbf{R}^{2}$ & 0.84 & 0.82 & 0.82 & 0.83 & 0.93 & 0.81 & 0.73 & 0.74 & 0.72 & 0.88 & 0.69 & 0.35 & 0.40 & 0.26 & 0.80 \\
\hline Adjusted $\mathrm{R}^{2}$ & 0.83 & 0.81 & 0.81 & 0.82 & 0.92 & 0.80 & 0.72 & 0.73 & 0.70 & 0.88 & 0.67 & 0.32 & 0.37 & 0.22 & 0.79 \\
\hline
\end{tabular}

Note: Values in parentheses are corresponding $\mathrm{p}$ values for t-test. 
Table 7. OLS regressions for Index A (intensity) sub-categories.

\begin{tabular}{|c|c|c|c|c|c|c|c|c|c|c|c|c|c|c|c|}
\hline \multicolumn{16}{|c|}{ Dependent indicator: GNI per capita } \\
\hline & \multicolumn{5}{|l|}{ Model 4} & \multicolumn{5}{|l|}{ Model 5} & \multicolumn{5}{|c|}{ Model 6} \\
\hline & 4.1 & 4.2 & 4.3 & 4.4 & 4.5 & 5.1 & 5.2 & 5.3 & 5.4 & 5.5 & 6.1 & 6.2 & 6.3 & 6.4 & 6.5 \\
\hline Index1: Production Capability & $\begin{array}{l}1467 \\
(0.000)\end{array}$ & $\begin{array}{l}2289 \\
(0.000)\end{array}$ & $\begin{array}{l}2181 \\
(0.000)\end{array}$ & $\begin{array}{l}2493 \\
(0.000)\end{array}$ & $\begin{array}{l}1189 \\
(0.000)\end{array}$ & & & & & & & & & & \\
\hline Index2: Technology capability & & & & & & $\begin{array}{l}1291 \\
(0.000)\end{array}$ & $\begin{array}{l}1905 \\
(0.000)\end{array}$ & $\begin{array}{l}1917 \\
(0.000)\end{array}$ & $\begin{array}{l}2096 \\
(0.000)\end{array}$ & $\begin{array}{l}859 \\
(0.000)\end{array}$ & & & & & \\
\hline Index3: R\&D capability & & & & & & & & & & & $\begin{array}{l}1534 \\
(0.000)\end{array}$ & $\begin{array}{l}1861 \\
(0.000)\end{array}$ & $\begin{array}{l}1894 \\
(0.000)\end{array}$ & $\begin{array}{l}1990 \\
(0.000)\end{array}$ & $\begin{array}{l}1136 \\
(0.000)\end{array}$ \\
\hline Constant & $\begin{array}{l}10521 \\
(0.071)\end{array}$ & $\begin{array}{l}-4278 \\
(0.271)\end{array}$ & $\begin{array}{l}-1583 \\
(0.662)\end{array}$ & $\begin{array}{l}5144 \\
(0.082)\end{array}$ & $\begin{array}{l}782 \\
(0.665)\end{array}$ & $\begin{array}{l}21790 \\
(0.000)\end{array}$ & $\begin{array}{l}12436 \\
(0.000)\end{array}$ & $\begin{array}{l}12405 \\
(0.000)\end{array}$ & $\begin{array}{l}9218 \\
(0.000)\end{array}$ & $\begin{array}{l}8664 \\
(0.000)\end{array}$ & $\begin{array}{l}5152 \\
(0.224)\end{array}$ & $\begin{array}{l}-2077 \\
(0.394)\end{array}$ & $\begin{array}{l}-2512 \\
(0.355)\end{array}$ & $\begin{array}{l}-3228 \\
(0.111)\end{array}$ & $\begin{array}{l}926 \\
(0.514)\end{array}$ \\
\hline Dummy MI & $\begin{array}{l}-13093 \\
(0.003)\end{array}$ & & & & & $\begin{array}{l}-16604 \\
(0.000)\end{array}$ & & & & & $\begin{array}{l}-7948 \\
(0.022)\end{array}$ & & & & \\
\hline Dummy LMI & & $\begin{array}{l}-2007 \\
(0.651)\end{array}$ & & & & & $\begin{array}{l}-10947 \\
(0.008)\end{array}$ & & & & & $\begin{array}{l}-3740 \\
(0238)\end{array}$ & & & \\
\hline Dummy UMI & & & $\begin{array}{l}-5672 \\
(0.085)\end{array}$ & & & & & $\begin{array}{l}-5887 \\
(0.103)\end{array}$ & & & & & $\begin{array}{l}-1775 \\
(0.504)\end{array}$ & & \\
\hline Dummy LHI & & & & $\begin{array}{l}-6322 \\
(0.077) \\
\end{array}$ & & & & & $\begin{array}{l}1684 \\
(0.659)\end{array}$ & & & & & $\begin{array}{l}-4108 \\
(0.125)\end{array}$ & \\
\hline Dummy UHI & & & & & $\begin{array}{l}25600 \\
(0.000) \\
\end{array}$ & & & & & $\begin{array}{l}26547 \\
(0.000) \\
\end{array}$ & & & & & $\begin{array}{l}19824 \\
(0.000) \\
\end{array}$ \\
\hline Number of observations & 42 & 42 & 42 & 42 & 42 & 42 & 42 & 42 & 42 & 42 & 42 & 42 & 42 & 42 & 42 \\
\hline F-test sig. & 0.000 & 0.000 & 0.000 & 0.000 & 0.000 & 0.000 & 0.000 & 0.000 & 0.000 & 0.000 & 0.000 & 0.000 & 0.000 & 0.000 & 0.000 \\
\hline $\mathbf{R}^{2}$ & 0.74 & 0.67 & 0.69 & 0.69 & 0.90 & 0.78 & 0.67 & 0.63 & 0.61 & 0.85 & 0.83 & 0.81 & 0.81 & 0.82 & 0.92 \\
\hline Adjusted $\mathbf{R}^{2}$ & 0.72 & 0.65 & 0.68 & 0.68 & 0.89 & 0.77 & 0.65 & 0.61 & 0.59 & 0.85 & 0.82 & 0.80 & 0.80 & 0.81 & 0.92 \\
\hline
\end{tabular}

Note: Values in parentheses are corresponding $\mathrm{p}$ values for $\mathrm{t}$-test. 
Table 8. OLS regressions for Index B (breadth) sub-categories.

\begin{tabular}{|c|c|c|c|c|c|c|c|c|c|c|c|c|c|c|c|}
\hline \multicolumn{16}{|c|}{ Dependent indicator: GNI per capita } \\
\hline & \multicolumn{5}{|c|}{ Model 7} & \multicolumn{5}{|c|}{ Model 8} & \multicolumn{5}{|l|}{ Model 9} \\
\hline & 7.1 & 7.2 & 7.3 & 7.4 & 7.5 & 8.1 & 8.2 & 8.3 & 8.4 & 8.5 & 9.1 & 9.2 & 9.3 & 9.4 & 9.5 \\
\hline $\begin{array}{l}\text { Index4: } \\
\text { Infrastructure: } \\
\text { Human and } \\
\text { physical }\end{array}$ & $\begin{array}{l}1644 \\
(0.000)\end{array}$ & $\begin{array}{l}2427 \\
(0.000)\end{array}$ & $\begin{array}{l}2487 \\
(0.000)\end{array}$ & $\begin{array}{l}2725 \\
(0.000)\end{array}$ & $\begin{array}{l}1285 \\
(0.000)\end{array}$ & & & & & & & & & & \\
\hline $\begin{array}{l}\text { Index5: Structural } \\
\text { change indicators }\end{array}$ & & & & & & $\begin{array}{l}934 \\
(0.021)\end{array}$ & $\begin{array}{l}1819 \\
(0.001)\end{array}$ & $\begin{array}{l}1936 \\
(0.000)\end{array}$ & $\begin{array}{l}2212 \\
(0.000)\end{array}$ & $\begin{array}{l}842 \\
(0.003)\end{array}$ & & & & & \\
\hline $\begin{array}{l}\text { Index6: Firm-level } \\
\text { organisational } \\
\text { capabilities }\end{array}$ & & & & & & & & & & & $\begin{array}{l}1164 \\
(0.000)\end{array}$ & $\begin{array}{l}1639 \\
(0.000)\end{array}$ & $\begin{array}{l}1647 \\
(0.000)\end{array}$ & $\begin{array}{l}1824 \\
(0.000)\end{array}$ & $\begin{array}{l}694 \\
(0.002)\end{array}$ \\
\hline constant & $\begin{array}{l}-370 \\
(0.963) \\
\end{array}$ & $\begin{array}{l}-18412 \\
(0.001) \\
\end{array}$ & $\begin{array}{l}-19400 \\
(0.002) \\
\end{array}$ & $\begin{array}{l}-23060 \\
(0.000) \\
\end{array}$ & $\begin{array}{l}-7355 \\
(0.032) \\
\end{array}$ & $\begin{array}{l}11020 \\
(0.221) \\
\end{array}$ & $\begin{array}{l}-15898 \\
(0.125) \\
\end{array}$ & $\begin{array}{l}-16112 \\
(0.081) \\
\end{array}$ & $\begin{array}{l}-25223 \\
(0.009) \\
\end{array}$ & $\begin{array}{l}-5361 \\
(0.289) \\
\end{array}$ & $\begin{array}{l}14176 \\
(0.000) \\
\end{array}$ & $\begin{array}{l}1546 \\
(0.630) \\
\end{array}$ & $\begin{array}{l}2535 \\
(0.450) \\
\end{array}$ & $\begin{array}{l}-3277 \\
(0.294) \\
\end{array}$ & $\begin{array}{l}4367 \\
(0.042) \\
\end{array}$ \\
\hline Dummy MI & $\begin{array}{l}-13237 \\
(0.002) \\
\end{array}$ & & & & & $\begin{array}{l}-21192 \\
(0.000) \\
\end{array}$ & & & & & $\begin{array}{l}-16861 \\
(0.000) \\
\end{array}$ & & & & \\
\hline Dummy LMI & & $\begin{array}{l}-6503 \\
(0.109) \\
\end{array}$ & & & & & $\begin{array}{l}-10249 \\
(0.069) \\
\end{array}$ & & & & & $\begin{array}{l}-9363 \\
(0.025) \\
\end{array}$ & & & \\
\hline Dummy UMI & & & $\begin{array}{l}-3272 \\
(0.345) \\
\end{array}$ & & & & & $\begin{array}{l}-11239 \\
(0.008) \\
\end{array}$ & & & & & $\begin{array}{l}-8017 \\
(0.018) \\
\end{array}$ & & \\
\hline Dummy LHI & & & & $\begin{array}{l}-4904 \\
(0.167) \\
\end{array}$ & & & & & $\begin{array}{l}-1211 \\
(0.805) \\
\end{array}$ & & & & & $\begin{array}{l}4276 \\
(0.253) \\
\end{array}$ & \\
\hline Dummy UHI & & & & & $\begin{array}{l}24535 \\
(0.000) \\
\end{array}$ & & & & & $\begin{array}{l}30065 \\
(0.000) \\
\end{array}$ & & & & & $\begin{array}{l}26594 \\
(0.000) \\
\end{array}$ \\
\hline $\begin{array}{l}\text { Number of } \\
\text { observations }\end{array}$ & 42 & 42 & 42 & 42 & 42 & 42 & 42 & 42 & 42 & 42 & 42 & 42 & 42 & 42 & 42 \\
\hline F-test sig. & 0.000 & 0.000 & 0.000 & 0.000 & 0.000 & 0.000 & 0.000 & 0.000 & 0.000 & 0.000 & 0.000 & 0.000 & 0.000 & 0.000 & 0.000 \\
\hline $\mathbf{R}^{2}$ & 0.74 & 0.69 & 0.68 & 0.69 & 0.88 & 0.68 & 0.42 & 0.47 & 0.37 & 0.84 & 0.81 & 0.66 & 0.67 & 0.63 & 0.84 \\
\hline Adjusted $\mathrm{R}^{2}$ & 0.73 & 0.68 & 0.66 & 0.67 & 0.88 & 0.66 & 0.40 & 0.45 & 0.34 & 0.83 & 0.80 & 0.65 & 0.65 & 0.61 & 0.84 \\
\hline
\end{tabular}

Note: Values in parentheses are corresponding $p$ values for $t$-test. 
A series of OLS regressions with middle-income dummy enable us to compare coefficients on middle-income dummies and get a ranking of sizes of these coefficients (Table 9). The higher the coefficient at a similar level of robustness (t-test) of dummy variable the higher the middle-income trap in that respective dimension of technology upgrading. Data below show dummy coefficients for middle-income group ranked in descending order of size.

Table 9. Comparison of MI dummies across OLS regression models.

\begin{tabular}{|c|c|c|c|c|c|c|}
\hline Dummy & MI Coef. & Std. Err. & $\mathbf{t}$ & $P>|t|$ & {$[95 \%$ Conf. } & Interval] \\
\hline Index C: Technology and knowledge exchange & -22795.7 & 3076.517 & -7.41 & 0.000 & $-29018.54-$ & -16572.86 \\
\hline Index 5: Structural change & -21192.28 & 3467.552 & -6.11 & 0.000 & -28206.07 & -14178.49 \\
\hline Index 6: Firm level organisational capabilities & -16860.6 & 2664.257 & -6.33 & 0.000 & -22249.57 & -11471.63 \\
\hline Index 2: Technology capability & -16603.51 & 2982.927 & -5.57 & 0.000 & -22637.05 & -10569.97 \\
\hline Index 4: Infrastructure: Human and capital & -13236.51 & 3943.269 & -3.36 & 0.000 & -21212.53 & -5260.499 \\
\hline Index 1: Production capability & -13093.33 & 4118.349 & -3.18 & 0.003 & -21423.47 & -4763.179 \\
\hline Index 3: R\&D capability & -7947.903 & 3335.741 & -2.38 & 0.022 & -14695.08 & -1200.73 \\
\hline
\end{tabular}

The biggest coefficient is in regression with index C: technology and knowledge exchange (interaction with global economy) followed by the index of structural change. The highest coefficient on the middle-income dummy for the index of technology and knowledge exchange suggests that given the level of knowledge and technology exchange income of middle-income countries are lower by 22795 USD per capita. This means that middle-income economies are not benefiting from being engaged in global technology and knowledge exchange as much as they should when compared to other income groups. In a nutshell, this suggests that they should better use their existing levels of technology and knowledge exchange, i.e. make them complementary to their technology generation and absorption.

The second biggest coefficient on a middle-income dummy is the index of structural change. Despite their intensive technology upgrading through structural change middle-income economies record levels of income lower by 21192 units when compared to other income groups. This may not be surprising given evidence on structural change and growth discussed earlier in the paper. Technology and knowledge exchange and structural change are therefore two the most significant dimensions of technology upgrading where the middle-income trap is visible. 
We can label next group of variables as of medium importance regarding middle-income trap. Organisational firm-level capability, technology capability, infrastructure and R\&D capability are dimensions of technology upgrading where the middle-income trap is of medium importance. Coefficients on middle-income dummies for these dimensions of technology upgrading are in between 16860 (organisational firm-level capabilities) and 13093 (production capability). Finally, the smallest dummy coefficient is for R\&D capability which is significant only at $5 \%$ level.

\section{DISCUSSION AND CONCLUSIONS}

We approached the issues of technology upgrading through a new conceptual and statistical framework geared towards broadly defined middle-income economies. The measurement is based on 35 indicators of both 'hard' and 'soft' nature, and they are applied to a balanced sample of 42 countries ranging from lower middle income to upper high income. Indicators have been selected based on their conceptual relevance, on their availability and relationship to income levels. We apply composite index methodology and check for robustness of groupings.

Our results are tentative and exploratory rather than hypothesis testing type. They show that there is a robust and positive relationship between indexes of technology upgrading and income levels. However, the relationship between the indexes of technology upgrading and income hides the fact that there does not seem to be any relationship in middle-income groups. This may be expected, as drivers of growth are more related to technology capability as the income levels of countries increase. Middle-income economies grow based on factors related to production capability and availability of labour and low labour costs. There seems to be a kind of threshold from middleincome group to lower and upper high-income groups where the relationship between income level and technology upgrading changes dramatically into positive.

A broadly defined middle-income trap is present in all dimensions of technology upgrading, but its importance varies across different aspects. The trap is highest for the index of interactions and knowledge exchange. Then, it seems to be higher for dimensions of the breadth of technology upgrading than for index of intensity of technology upgrading. Index of the intensity of technology upgrading reflects cumulative technology capability while the index of the breadth of technology upgrading refers to structural, infrastructural and organisational features of economies. These latter are subject to various market and system failures and are outcomes of a variety of non-technological factors (cf. political economy of the country). So, though structurally middle income may seem similar to higher income economies, this structural similarity does not convert into their income 
levels. A much stronger convergence regarding breadth of or scope of technology upgrading is due to smaller differences in infrastructure but especially due to the intensive process of structural change which takes place at different levels of different income groups. Much of the differences regarding the breadth of technology upgrading are mainly due to the third component - differences regarding firm-level organisational capabilities which are the biggest within (not between) different income groups.

Technology and knowledge exchange component of technology upgrading does not add to index in a cumulative manner. In other words, increased technology and knowledge exchange with the global economy does not necessarily increase the potential for growth based on technology. The relationship between Index C: interaction with the global economy, which is based on proxies of knowledge and technology exchanges is not robust due to several 'outliers' (Ireland, Belgium, Hungary, Greece) but also there is a much weaker relationship when compared to the other two indexes of technology upgrading. There is not a clear relationship between knowledge and technology exchange intensity and middle-income levels group based on the R-squared values of models. The interaction with the global economy regarding technology and knowledge exchange is very much country and not income specific. A strong technology and knowledge inflow operates as a substitute or as a complement to own technology efforts recorded in other indexes. The highest coefficient on a middle-income dummy, on the other hand, is the index of technology and knowledge exchange. This suggests that middle-income economies are not benefiting from being engaged in global technology and knowledge exchange as much as they should in comparison to other income groups. In a nutshell, this suggests that they should better use their existing levels of technology and knowledge exchange, i.e. exploit their complementarities to their technology generation and absorption.

In conclusion, although initially intended, we have given up of constructing an aggregate index of technology upgrading, which would be composed of indexes of intensity and breadth of technology upgrading, and interaction with the global economy. Although, statistically this is possible we do not consider it justifiable conceptually, empirically and from the policy perspective. Such index would hide rather than reveal the three qualitatively different drivers of technology upgrading.

We believe that our conceptual and statistical attempt to depict technological upgrading of middleincome economies has demonstrated its relevance and analytical value. We believe that the conceptual approach has proven resilient and able to withstand the test of a battery of indicators that we have tested in the initial stage of research. The ranking of countries based on individual indexes of technology upgrading is quite revealing as they show potential for technology-based 
growth, which sometimes may widely differ from the recent growth figures or macroeconomics forecasts. In that respect, indexes of technology upgrading may serve as a very useful complement in understanding long-term drivers of growth.

As would be expected, the choice and selection of indicators will remain an issue for further work, but the majority of indicators has shown their relevance and link to our conceptual model. Analytical value of the three-pronged composite indicator of technology upgrading is quite relevant as it focuses metrics on dimensions of technology upgrading that matter for the growth of broadly defined middle-income economies. Equally, our research shows the limits of aggregate composite indicators and need to ground them in the consistent conceptual basis.

\section{REFERENCES}

Amsden, A. H. (2001) The Rise Of "The Rest". Challenges to the West from Late-Industrializing Economies, Oxford University Press.

Amsden, A. H. and Hikino, T. (1994) Project execution capability, organisational know-how and conglomerate corporate growth in late industrialisation, Industrial and Corporate Change 3, pp. 111148.

Amsden A. H. and Tschang, F.H. (2003) A new approach to assessing the technological complexity of different categories of R\&D (with examples from Singapore), Research Policy 32 (2003) 553-572

Anderson, J.C., and Gerbing, D.W. (1988) Structural equation modelling in practice: a review of recommended two-stage approach. Psychological Bulletin 103 (3), 411-423.

Archibugi, D. and Coco, A. (2004) A new indicator of technological capabilities for developed and developing countries. World Development 32 (4), 629-654.

Archibugi, D. and Coco, D. (2005) Measuring technological capabilities at the country level: A survey and a menu for choice, Research Policy 34 (2005) 175-194

Archibugi, D., Denni, M. and Filippetti, A. (2009) 'The technological capabilities of nations: A review of the synthetic indicators'. Technological Forecasting and Social Change, Vol. 76, No. 7, pp. 917-31.

Baroncelli, E., Fink, C. and Smarzynska Javorcik, B. (2004) The Global Distribution of Trademarks: Some Stylised Facts World Bank Policy Research Working Paper 3270, April 2004

Bell, M. and K. Pavitt (1993) Technological Accumulation and Industrial Growth: Contrasts between developed and developing countries, Industrial and Corporate Change, 2(2): 157-210.

Bruno R. L. and Campos, N.F. (2013) Reexamining the Conditional Effect of Foreign Direct Investment, IZA Discussion Paper No. 7458, June 2013. Available at http://papers.ssrn.com/sol3/papers.cfm?abstract id=2287068

Castellacci, F. (2011) Closing the technology gap? Review of Development Economics 15, 180-197. 
Chen, D. H. C. and Dahlman, C. J. (2004) Knowledge and Development: A Cross-Section Approach. Policy Research Working Paper Series No. 3366. World Bank, Washington, D.C.

Chen, D. H. C. and Dahlman, C. J. (2005) The Knowledge Economy, the KAM Methodology and World Bank Operations, The World Bank Washington DC 20433.

Choung, J. Y., Hwang, H.R. and Song, W. (2014) Transitions of Innovation Activities in Latecomer Countries: An Exploratory Case Study of South Korea, World Development Vol. 54, pp. 156-167.

Cohen, W. and Levinthal, D. (1989) Innovation and Learning: Two Faces of R\&D, Economic Journal 99, 569-596.

Crépon, B., E. Duguet and J. Mairesse (1998), "Research and Development, Innovation and Productivity: An Econometric Analysis at the Firm Level", Economics of Innovation and New Technology, 7(2), 115-158.

Dahlman, C., Ross-Larsen, B. and Westphal, L.E. (1987) Managing technological development: Lessons from the Newly Industrializing Countries, World Development, Vol.15, No. 6, 759-775.

Desai, M., Fukuda-Parr, S., Johansson, C. and Sagasti, F. (2002) Measuring the technology achievement of nations and the capacity to participate in the network age. Journal of Human Development 3 (1), 95-122.

Ernst, D. (2014) Upgrading India's electronics manufacturing industry: regulatory reform and industrial policy, East West Centre, Honolulu,

Fagerberg, J. (1987) A technology gap approach to why growth rates differ. Research Policy 16, 8799.

Fagerberg, J. and Verspagen, B. (2002) Technology-gaps, Innovation-diffusion and Transformation: an Evolutionary Interpretation. Research Policy 31, 1291-1304.

Freudenberg, M. (2003) Composite indicators of country performance: a critical assessment. STI Working Paper 2003/16, OECD.

GCR (2010) The Global Competitiveness Report 2010-2011, World Economic Forum, Geneva.

GCR (2015) The Global Competitiveness Report 2015-2016, World Economic Forum, Geneva.

Griffith, R., Redding, S. and Van Reenen, J. (2003). 'R\&D and Absorptive Capacity: from theory to data', The Scandinavian Journal of Economics, 105 (1), 99-118.

Griibler, A. (1990) The Rise and Fall of Infrastructures. Dynamics of Evolution and Technological Change in Transport, Physica-Verlag, Heidelberg, Germany.

Holmes, T. J., McGrattan, E.R. and Prescott, E.C. (2015) “Quid Pro Quo: Technology Capital Transfers for Market Access in China" Review of Economic Studies 82, 1154-1193.

Hu, A. G., Jefferson, G. H. (2009) A great wall of patents: What is behind China's recent patent explosion? Journal of Development Economics 90, 57-68.

INSEAD, Cornell University and WIPO (2014) The Global Innovation Index 2014: The Human

Factor In innovation, Fontainebleau, Ithaca, and Geneva. 
Khanna, T. and Yafeh, Y. (2007) Business Groups in Emerging Markets: Paragons or Parasites? Journal of Economic Literature, June, Vol. XLV, No. 2, pp. 331-372

Kim, L. (1980) Stages of development of industrial technology in a less developed country: a model, Research Policy 9(3):254-277

Kim, L. (1997) Imitation to Innovation: The Dynamics of Korea's Technological Learning, Boston,

Kneller, R. and Stevens, P.A. (2006) Frontier Technology and Absorptive Capacity: Evidence from OECD Manufacturing Industries, Oxford Bulletin of Economics and Statistics, 68(1), 1-21.

Koopmans, T.C. (1947) Measurement without theory, Rev. Econ. Stat. 29 (3), 161-172.

Krueger, J. J. (2008) Productivity and structural change: a review of the literature, Journal of Economic Surveys, Volume 22, Issue 2, April, Pages 330-363

Lall, S. (1992) Technological capabilities and industrialisation, Research Policy, 20(2), 165-186.

Lall, S. and Albaladejo, M. (2002) Indicators of relative importance of IPRs in developing countries. Background Paper for ICTSD/UNCTAD Capacity Building Project on Trips and Development. Working Paper No. 85. Oxford: Queen Elizabeth House, University of Oxford.

Lazonick, W. (2002) "The Theory of Innovative Enterprise", In Malcolm Warner, ed., International Encyclopaedia of Business and Management, Thomson Learning, 3055-3076.

Lee, K., Km, B. Y., Park, Y. and Sanidas, E. (2013) Big business and economic growth: identifying a binding constraint for growth with country panel analysis, Journal of Comparative Economics, 41 (2):561-82

Lee, K. (2013) Schumpeterian analysis of economic catch-up, Knowledge, Path-creation and the middle-income trap, Cambridge University Press

Levine, D., I. and Toffel, M. W. (2009) Quality Management and Job Quality: How the ISO 9001 Standard for Quality Management Systems Affects Employees and Employers, Harvard Business School Working Paper 09-18.

Lucas, R.E. (1988), "On the Mechanics of Economic Development", Journal of Monetary Economics, Vol. 22, pp. 3-42.

Mendonca, S., Pereira, T.G. and Godhino, M. M. (2004) Trademarks as an indicator of innovation and industrial change, Paper presented at the DRUID Summer Conference Industrial Dynamics, Innovation and Development, Elsinore, Denmark, June 14-16, 2004

Millot, V. (2009) Trademarks as an Indicator of Product and Marketing Innovations, STI Working Paper 2009/6, OECD

Morck, R., Wolfenzon, D. And Yeung, B. (2005) Corporate Governance, Economic Entrenchment, and Growth, Journal of Economic Literature, Vol. XLIII (September 2005), pp. 655-720

Mowery, D.C. and J. Oxley (1997) "Inward Technology Transfer and Competitiveness: The Role of National Innovation Systems", in Technology, Globalisation and Economic Performance, D. Archibugi and J. Michie (eds.), Cambridge University Press.

Munda, G. and Nardo, M. (2009) Non-compensatory/Nonlinear composite indicators for ranking countries: a defensible setting. Applied Economics 41 (12), 1513-1523. 
Nasierowski, W. and Arcelus, F.J. (2000) On Perceptions of Technical Efficiency of the Basis of the Innovation Union Scoreboard Nelson Richard R. and Sidney G. Winter (1985), An Evolutionary Theory of Economic Change, Belknap Press.

Nunnally, J. (1978) Psychometric Theory. McGraw-Hill, New York.

OECD, 2003. The Sources of Economic Growth in OECD Countries, OECD, Paris

OECD, 2008. Handbook on Constructing Composite Indicators: Methodology and User Guide. OECD, Paris.

Radosevic, S. (1999) International technology transfer and catch-up in economic development, Edward Elgar, Cheltenham.

Radosevic, S. and Yoruk, E. (2011) Entrepreneurial Propensity of Innovation Systems: A Preliminary Analysis with Composite Indexes in EU Countries. DIME Workshop on "Regional Innovation and Growth: Theory, Empirics and Policy Analysis" University of Pecs, Hungary, March 31 - April 12011.

Radosevic, S. and Yoruk, E. (2016a) Why do we need theory and metrics of technology upgrading? Asian Journal of Technology Innovation, 24(Sup 1), 8-32. http://dx.doi.org/10.1080/19761597.2016.1207415.

Radosevic, S. and Yoruk, E. (2016b) A New Metrics of Technology Upgrading: The Central And East European Countries in a Comparative Perspective, GRINCOH Working paper series, Series 3 Knowledge Innovation, Technology, Paper no.3.04.

Reinstaller, A. and Unterlass, F. (2011) Sectoral Innovation Modes and the State of Economic Development: Implications for Innovation Policy in the New Member States. In: Radosevic S., Kaderabkova, A. (Eds.). Innovation Policy in Multi-Tier Europe. The Specific Challenges of the Central and Eastern European Countries. Aldershot: Edward Elgar.

Romer, P.M. (1990), "Endogenous Technological Change", Journal of Political Economy, Vol. 98, No. 5, pp. 71-102

Romp, W. and J. de Haan (2005), 'Public capital and economic growth: a critical survey', EIB Papers, 10(1)

Stevenson, H. T. and Barnes, F.C. (2001) Fourteen Years of ISO 9000: Impact, Criticisms, Costs, and Benefits, Business Horizons, May/June: 45-51

Terlakk, A. and King, A.A. (2006) The effect of certification with the ISO9000 Quality Management Standard: A signalling approach, Journal of Economic Behavior \& Organization Vol. 60 (2006) 579602.

UNIDO (2002) Industrial Development Report 2002-2003: Connecting Through Innovation and Learning. United Nations Industrial development Organization.

Van Zeebroeck, N. (2011) The puzzle of patent value indicators, Economics of Innovation and New Technology, 20:1, 33-62, DOI: 10.1080/10438590903038256Von Tunzelmann, G.N. (1995) Technology and Industrial Progress: The Foundations of Economic Growth, Edward Elgar, Aldershot.

WCY (2016) IMD World Competitiveness Yearbook, Switzerland and Singapore.

Yoruk, D.E. (2013) Firm-level upgrading in low- and medium-technology industries in emerging markets: the role of learning networks, PhD thesis, University of Sussex, December, SPRU. 
Yoruk, E. (2011) 'The influence of technological capabilities on the knowledge network component of innovation systems: evidence from advanced materials in Turkey'. International Journal of Technological Learning, Innovation and Development 4, (4), 330-362.

Yoruk, E., and Yoruk, D. E. (2012) 'Determinants of Innovation in Emerging Market SMEs: Thirty-Five Years. Evidence from Advanced Materials in Turkey'. In Katzy, B., Holzmann, T., Sailer, K., and Thoben, K-D. (eds.) ICE 2012 Conference Proceedings, 'IEEE International Technology Management Conference'. Held 18-20 June 2012 in Munich, Germany. Munich: Strascheg Centre for Entrepreneurship, 1-30.

\section{Appendix A}

Selected countries by level of income per capita in 2013.

\begin{tabular}{|c|c|c|c|}
\hline $\begin{array}{l}\text { Lower Middle Income } \\
\text { (GNI pc Atlas method } \\
\text { \$1046-4125) }\end{array}$ & $\begin{array}{l}\text { Upper Middle Income } \\
\text { (GNI pc Atlas method } \\
\$ 4126-12745)\end{array}$ & $\begin{array}{l}\text { Lower High Income } \\
\text { (GNI pc Atlas method } \\
\$ 12176-30000)\end{array}$ & $\begin{array}{l}\text { Upper High Income } \\
\text { (GNI pc Atlas method } \\
\$ 30001-\text { ) }\end{array}$ \\
\hline $\begin{array}{l}\text { Ghana } \\
\text { India } \\
\text { Indonesia } \\
\text { Moldova } \\
\text { Morocco } \\
\text { Philippines } \\
\text { Ukraine } \\
\text { Vietnam }\end{array}$ & $\begin{array}{l}\text { Albania } \\
\text { Belarus } \\
\text { Brazil } \\
\text { Bulgaria } \\
\text { China } \\
\text { Hungary } \\
\text { Jordan } \\
\text { Kazakhstan } \\
\text { Malaysia } \\
\text { Mexico } \\
\text { Peru } \\
\text { Romania } \\
\text { South Africa } \\
\text { Thailand } \\
\text { Turkey }\end{array}$ & $\begin{array}{l}\text { Chile } \\
\text { Czech Republic } \\
\text { Estonia } \\
\text { Greece } \\
\text { Korea } \\
\text { Poland } \\
\text { Portugal } \\
\text { Russia } \\
\text { Slovenia } \\
\text { Spain }\end{array}$ & $\begin{array}{l}\text { Austria } \\
\text { Belgium } \\
\text { Germany } \\
\text { Ireland } \\
\text { Italy } \\
\text { Japan } \\
\text { Norway } \\
\text { Sweden } \\
\text { UK } \\
\text { USA }\end{array}$ \\
\hline
\end{tabular}

\section{Appendix B Explanations for Composite Index Measures}

\section{Technology upgrading intensity index (INDEX A)}

Type and intensity of technology upgrading lie in the production and technology capabilities and skills of enterprises and the population, investments and outputs in new knowledge creation and generation, and the extent of R\&D activities. They are essential to technology upgrading as without them product and process innovations could not be developed.

Index A is composed of three components: Production capability (Index 1), technology capability (Index 2) and R\&D and knowledge intensity (Index 3). Accordingly:

Index $A=$ Index $1+$ Index $2+$ Index 3 
Production capability (Index 1 ) intends to capture the rate of activities and output in relation to production activity. It is composed of three indicators:

1. ISO9001 certificates (per million inhabitants) is taken from International Organization for Standardization (ISO), and an average of 2007-2011 values is used in the analysis.

2. Trademark applications, resident (per million inhabitants) is taken from World Intellectual Property Organization (WIPO), and an average of 2007-2011 values is used in the analysis.

3. On the job training is taken from World Economic Forum Global Competitiveness Report (WEF GCR) Question 5.C and 2012-13 value is used in the analysis. This is a combination of two manifest indicators Question 5.07 Local availability of specialised training services (asks the question 'In your country, how available are high quality professional training services?') and Question 5.08 Extent of staff training (asks the question 'In your country, to what extent companies invest in training and employee development?).

Technology capability (Index 2 ) is built on measuring technology generation capabilities, mainly patents. It is composed of four indicators drawn from World Intellectual Property Organization (WIPO), and averages of 2007-2011 values are used in the analysis:

4. Patents resident applications to national office (per million inhabitants)

5. Patent applications to USPTO (per million inhabitants)

6. Patent applications to EPO (per million inhabitants)

7. Resident's industrial design count (per million inhabitants)

$R \& D$ and knowledge and intensity (Index 3 ) intend to capture the knowledge developed by investments in R\&D as well as the influence of capabilities embodied in people, i.e. R\&D personnel, scientists and their publication outputs. It draws on eight indicators:

8. Business Enterprise Sector R\&D expenditures (\% of GDP) is taken from UNESCO for the year 2011.

9. Research and development expenditure (\% of GDP) is taken from World Bank for the year 2011.

10. Researchers in R\&D (per million inhabitants) is taken from World Bank for the year 2010.

11. Technicians in R\&D (per million inhabitants) is taken from World Bank for the year 2010.

12. Scientific and technical journal articles (per million inhabitants) is taken from World Bank, and an average of 2007-2011 values is used in the analysis.

13. Science citations (per million inhabitants) is taken from Thomson National Science Indicators and average of 2007-2011 values is used in the analysis.

14. The quality of scientific research institutions is taken from WEFGCR Question 12.02 for the year 2012-13. It is based on the question: How would you assess the quality of scientific research institutions in your country? [ 1 = very poor; 7 = the best in their field internationally]

15. University - industry collaboration in R\&D is taken from WEFGCR Question 12.04 for the year 2012-13. It is based on the question: To what extent do business and universities collaborate on research and development (R\&D) in your country? [ $1=$ do not collaborate at all; $7=$ collaborate extensively] 


\section{Technology upgrading breadth index (INDEX B)}

The breadth of technology upgrading lies in structural features and changes in these structural features. Structural features are based on the human capital, physical capital and organisational issues.

Index B is composed of three components: Human capital, physical and organizational infrastructure (Index 4), structural change (Index 5) and firm-level capabilities (Index 6). Accordingly:

Index $B=$ Index $4+$ Index $5+$ Index 6

Human capital, physical and organizational infrastructure (Index 4) is built on measuring the influence of capabilities embodied in people through the wider population with education, the respond to skills demand, the extent people exploit available infrastructural technologies and the level of fixed investment. Accordingly, it is composed of six manifest indicators:

1. Average years of schooling for ages $25+$ is taken from Barro-Lee database for the latest the available year 2010 .

2. The quality of maths and science education institutions is taken from WEFGCR Question 5.04 for the year 2012-13. It is based on the question: How would you assess the quality of math and science education in your country's schools? [ 1 = poor; 7 = excellent among the best in the world]

3. Availability of specialized research and training services is taken from WEFGCR Question 5.07 for the year 2012-13. It is based on the question: In your country, to what extent are high-quality, specialized training services available? $[1=$ not available; $7=$ widely available]

4. Availability of scientists and engineers is taken from WEFGCR Question 12.06 for the year 2012-13. It is based on the question: To what extent are scientists and engineers available in your country? [ 1 = not at all; 7 = widely available]

5. Fixed broadband Internet subscribers (per 100 people) is taken from World Bank for the year 2012

6. Gross Fixed Investment as \% of GDP is taken from World Bank for the year 2012.

Structural change (index 5) intends to capture over time changes in technology capability, demand structure and level of available technologies. It comprises seven indicators. The first three indicators use patent data from WIPO, USPTO and EPO to calculate Herfindahl-Hirschman Index. By this, we aim to assess the level of diversification by technology field/class in the patenting structure of the countries. The formula for Herfindahl-Hirschman index calculation is as below:

$$
H=\sum_{i=1}^{n} s_{i}^{2}
$$

Where $\mathrm{s}_{\mathrm{i}}$ is the share of patents of a country in a specific technology field. The index is calculated for each of the 42 countries based on WIPO technology classification (see Appendix E for a list of 35 technology fields). The same method is applied to calculate Herfindahl-Hirschman index for national patent applications (Indicator 22), applications to EPO (Indicator 23) and applications to USPTO (Indicator 24). 
7. Herfindahl-Hirschman Index for total national patent applications.

8. Herfindahl-Hirschman Index for patent applications to EPO

9. Herfindahl-Hirschman Index for patent applications to USPTO

10. Buyer sophistication is taken from WEFGCR Question 6.16 for the year 2012-13. It is based on the question: In your country, how do buyers make purchasing decisions? [1 = based solely on the lowest price; 7 = based on a sophisticated analysis of performance attributes]

11. Change in buyer sophistication( \% change in Q. 6.16 from 2006-07 to 2012-13)

12. Availability of state-of-the-art technologies is taken from WEFGCR Question 9.01 for the year 2012-13. It is based on the question: To what extent are the latest technologies available in your country? [ $1=$ not available; 7 = widely available $]$

13. Change in availability of latest technologies( \% change in 9.01 from 2006-07 to 2012-13)

Firm-level capabilities (Index 6) has two manifest indicators:

14. Number of firms in Forbes 2000 (per million inhabitants)

15. Firm-level technology absorption is taken from WEFGCR Question 9.02 for the year 2012-13. It is based on the question: To what extent do businesses in your country absorb new technology? [1 = not at all; 7 = aggressively absorb]

\section{Index of technology and knowledge exchange (ITKE)}

This index intends to capture the influence of global interactions of countries y which knowledge flows take place. We assess the impact of such interactions as complementary to technology upgrading. The index comprises five manifest indicators:

1. Licencing receipts as \% of GDP is taken from World Bank for the year 2012.

2. Licencing payments as \% of GDP is taken from World Bank for the year 2012.

3. The share of exports in complex industries in total exports (SITCRev3 5 71-79 87 88). Data for this indicator have been extracted from UNComtrade for years 2008-12 average. We calculated the share of exports in total exports of each country, particularly in SITC Rev.3 sectors 5 - Chemicals and related products, n.e.s.; 71 to 75 Machinery (Power generating machines, special industrial machinery, metalworking machinery, general industrial machinery, n.e.s, office machines); 76 - telecommunications equipment; 78-79 transport equipment (road vehicles, other transport equipment); 87-88 electrical and optical (scientific equipment, n..e.s., photo apparatus n.e.s., clocks).

4. Foreign direct investment, net outflows (\% of GDP) is taken from World Bank for the year 2007-2012 average.

5. Foreign direct investment, net inflows (\% of GDP) is taken from World Bank for the year 2007-2012 average. 


\section{Appendix C}

Factor analysis results.

\begin{tabular}{|c|c|c|c|c|c|c|c|c|}
\hline Index & Component & Quantitative Indicators & $\begin{array}{l}\text { One factor } \\
\text { solution } \\
\text { for } \\
\text { component } \\
\text { (CFA) }\end{array}$ & $\begin{array}{l}\text { Cumulative } \\
\text { explanation } \\
\text { of Factor }\end{array}$ & $\begin{array}{l}\text { Chi2 } \\
\text { (sig.) }\end{array}$ & $\begin{array}{l}\text { One } \\
\text { factor } \\
\text { solution } \\
\text { for } \\
\text { index } \\
\text { (CFA) }\end{array}$ & $\begin{array}{l}\text { Cumulative } \\
\text { explanation } \\
\text { of Factor }\end{array}$ & $\begin{array}{l}\text { Chi(2) } \\
\text { (sig.) }\end{array}$ \\
\hline \multirow{3}{*}{ 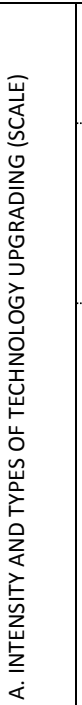 } & $\begin{array}{l}\text { 1. Production } \\
\text { capability }\end{array}$ & $\begin{array}{l}\text { 1.ISO9001 certificates pmi } \\
\text { 2.Trademark applications, resident pmi } \\
\text { 3.On the job training Q.5.C }\end{array}$ & $\begin{array}{l}0.28 \\
0.55 \\
0.47\end{array}$ & - & $\begin{array}{l}7.94 \\
(0.0473)\end{array}$ & \multirow{3}{*}{$\begin{array}{l}0.92 \\
0.76 \\
0.86 \\
0.75 \\
\\
0.90 \\
0.85 \\
0.83 \\
\\
0.78 \\
\\
0.40 \\
\\
0.60 \\
0.72 \\
0.60 \\
\\
0.78 \\
0.85 \\
0.57 \\
\end{array}$} & \multirow[t]{3}{*}{0.69} & \multirow[t]{3}{*}{$\begin{array}{l}729.90 \\
(0.0000)\end{array}$} \\
\hline & $\begin{array}{l}\text { 2. Technology } \\
\text { capability }\end{array}$ & $\begin{array}{l}\text { 4.Patents resident applications to national } \\
\text { office pmi } \\
\text { 5.Patent applications to USPTO pmi } \\
\text { 6.Patent applications to EPO pmi } \\
\text { 7.Resident's industrial design count pmi }\end{array}$ & $\begin{array}{l}0.83 \\
0.89 \\
0.71 \\
0.65\end{array}$ & 0.87 & $\begin{array}{l}97.2 \\
(0.0000)\end{array}$ & & & \\
\hline & $\begin{array}{l}\text { 3. R\&D and } \\
\text { knowledge } \\
\text { intensity }\end{array}$ & $\begin{array}{l}\text { 8.Business Enterprise Sector R\&D } \\
\text { expenditures (\% of GDP } \\
\text { 9.Research and development expenditure } \\
\text { (\% of GDP) } \\
\text { 10.Researchers in R\&D pmi } \\
\text { 11.Technicians in R\&D pmi } \\
\text { 12.Scientific and technical journal articles } \\
\text { pmi } \\
\text { 13.Science citations pmi } \\
\text { 14.The quality of scientific research } \\
\text { institutions Q.12.02 } \\
\text { 15.University - industry collaboration } \\
\text { Q.12.04 }\end{array}$ & $\begin{array}{l}0.87 \\
0.74 \\
\\
0.86 \\
0.79 \\
0.94 \\
\\
0.90 \\
0.85 \\
0.76\end{array}$ & 0.86 & $\begin{array}{l}383.24 \\
(0.0000)\end{array}$ & & & \\
\hline \multirow{3}{*}{ 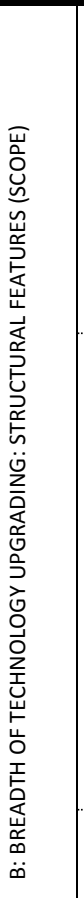 } & $\begin{array}{l}4 . \\
\text { Infrastructure: } \\
\text { human capital } \\
\text { and physical } \\
\text { and } \\
\text { organisational }\end{array}$ & $\begin{array}{l}\text { 16.Average years of schooling } 25+ \\
\text { 17.Quality of maths and science education } \\
\text { Q.5.04 } \\
\text { 18.Availability of research and training } \\
\text { services Q.5.07 } \\
\text { 19.Availability of scientists and engineers } \\
\text { Q.12.06 } \\
\text { 20.Fixed broadband Internet subscribers } \\
\text { (per } 100 \text { people) } \\
\text { 21.Gross Fixed Investment as \% of GDP }\end{array}$ & $\begin{array}{l}0.66 \\
0.51 \\
0.68 \\
0.57 \\
0.89 \\
-0.38\end{array}$ & 0.78 & $\begin{array}{l}95.53 \\
(0.0000)\end{array}$ & $\begin{array}{l}0.51 \\
0.37 \\
0.85 \\
0.66 \\
0.82 \\
-0.37\end{array}$ & 0.61 & $\begin{array}{l}293.27 \\
(0.0000)\end{array}$ \\
\hline & $\begin{array}{l}\text { 5. Structural } \\
\text { change }\end{array}$ & $\begin{array}{l}\text { 22. Herfindahl-Hirschman Index for total } \\
\text { national patent applications } \\
\text { 23.Herfindahl-Hirschman Index for patent } \\
\text { applications to EPO } \\
\text { 24.Herfindahl-Hirschman Index for patent } \\
\text { applications to USPTO } \\
\text { 25.Buyer sophistication Q.6.16 } \\
\text { 26.Change in buyer sophistication( \% } \\
\text { change in Q. } 6.16 \text { from 2006-07 to 2012- } \\
\text { 13) } \\
\text { 27.Availability of state-of-the-art } \\
\text { technologies Q.9.01 } \\
28 . \text { Change in availability of latest } \\
\text { technologies( \% change in } 9.01 \text { from 2006- } \\
07 \text { to 2012-13) }\end{array}$ & $\begin{array}{l}0.72 \\
0.27 \\
0.81 \\
-0.53 \\
0.63 \\
-0.65 \\
0.55\end{array}$ & 0.85 & $\begin{array}{l}93.55 \\
(0.0000)\end{array}$ & $\begin{array}{l}-0.59 \\
-0.41 \\
0.61 \\
-0.61 \\
0.80 \\
-0.49 \\
-0.53\end{array}$ & & \\
\hline & $\begin{array}{l}\text { 6. Firm-level } \\
\text { capabilities }\end{array}$ & $\begin{array}{l}\text { 29. Number of firms in Forbes } 2000 \mathrm{pmi} \\
\text { 30.Firm-level technology absorption } \\
\text { Q.9.02 }\end{array}$ & - & - & - - & $\begin{array}{l}0.75 \\
0.79\end{array}$ & & \\
\hline \multicolumn{2}{|l|}{ 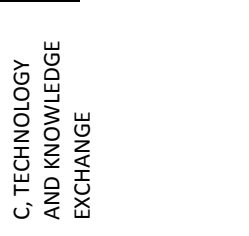 } & $\begin{array}{l}\text { 31.Licensing receipts as \% of GDP } \\
\text { 32.Licensing payments as \% of GDP } \\
\text { 33.Share of exports in complex industries } \\
\text { in total exports (SITCRev3 } 571-7987 \text { 8) } \\
\text { 34.Foreign direct investment, net outflows } \\
\text { (\% of GDP) } \\
\text { 35.Foreign direct investment, net inflows } \\
\text { (\% of GDP) }\end{array}$ & $\begin{array}{l}0.86 \\
0.76 \\
0.52 \\
\\
0.84 \\
\\
\end{array}$ & 0.83 & $\begin{array}{l}115.43 \\
(0.0000)\end{array}$ & & & \\
\hline
\end{tabular}

Note: Confirmatory Factor Analysis (CFA) is based on principal factors method in STATA. The commonalities are estimated using the squared multiple correlation coefficients. 
Appendix D.

Table. OLS regressions for indexes without level income dummies.

\begin{tabular}{|c|c|c|c|c|c|c|c|c|c|}
\hline & Model12a & Model13a & Model14a & Model15a & Model16a & Model17a & Model18a & Model19a & Model 20a \\
\hline $\begin{array}{l}\text { Index } 1 \\
\text { (production } \\
\text { capability) }\end{array}$ & $\begin{array}{l}4666.9 \\
(0.000)\end{array}$ & & & & & & & & \\
\hline $\begin{array}{l}\text { Index } 2 \\
\text { (technology } \\
\text { capability) }\end{array}$ & & $\begin{array}{l}4200 \\
(0.000)\end{array}$ & & & & & & & \\
\hline $\begin{array}{l}\text { Index } 3 \text { (R\&D } \\
\text { and knowledge } \\
\text { intensity) }\end{array}$ & & & $\begin{array}{l}3939 \\
(0.000)\end{array}$ & & & & & & \\
\hline $\begin{array}{l}\text { Index A } \\
\text { (Intensity) }\end{array}$ & & & & $\begin{array}{l}1676.5 \\
(0.000)\end{array}$ & & & & & \\
\hline $\begin{array}{l}\text { Index } 4 \\
\text { (infrastructure) }\end{array}$ & & & & & $\begin{array}{l}5058.6 \\
(0.000)\end{array}$ & & & & \\
\hline $\begin{array}{l}\text { Index 5 } \\
\text { (structural } \\
\text { change) }\end{array}$ & & & & & & $\begin{array}{l}5234.5 \\
(0.000)\end{array}$ & & & \\
\hline $\begin{array}{l}\text { Index } 6 \\
\text { (organisational } \\
\text { capabilities) }\end{array}$ & & & & & & & $\begin{array}{l}3538.6 \\
(0.000)\end{array}$ & & \\
\hline $\begin{array}{l}\text { Index B } \\
\text { (breadth) }\end{array}$ & & & & & & & & $\begin{array}{l}1951.5 \\
(0.000)\end{array}$ & \\
\hline $\begin{array}{l}\text { Index C } \\
\text { (interaction) }\end{array}$ & & & & & & & & & $\begin{array}{l}478.8 \\
(0.001)\end{array}$ \\
\hline Constant & $\begin{array}{l}-5646.4 \\
(0.084)\end{array}$ & $\begin{array}{l}9586.8 \\
(0.000)\end{array}$ & $\begin{array}{l}-4231.1 \\
(0.044)\end{array}$ & $\begin{array}{l}-3247.9 \\
(0.100)\end{array}$ & $\begin{array}{l}-21896.8 \\
(0.000)\end{array}$ & $\begin{array}{l}-34143.8 \\
(0.002)\end{array}$ & $\begin{array}{l}-2262.5 \\
(0.478)\end{array}$ & $\begin{array}{l}-27892.7 \\
(0.000)\end{array}$ & $\begin{array}{l}7531.4 \\
(0.041)\end{array}$ \\
\hline $\begin{array}{l}\text { No of } \\
\text { observations }\end{array}$ & 42 & 42 & 42 & 42 & 42 & 42 & 42 & 42 & 42 \\
\hline F-test sig. & 0.000 & 0.000 & 0.000 & 0.000 & 0.000 & 0.000 & 0.000 & 0.000 & 0.000 \\
\hline$\overline{\mathrm{R}^{2}}$ & 0.64 & 0.61 & 0.81 & 0.81 & 0.62 & 0.41 & 0.58 & 0.71 & 0.25 \\
\hline Adjusted $\mathbf{R}^{2}$ & 0.63 & 0.60 & 0.80 & 0.81 & 0.61 & 0.39 & 0.57 & 0.70 & 0.23 \\
\hline
\end{tabular}

Note: in brackets $p$ value for $t$ test. 


\section{Appendix E.}

WIPO patent technology classification.

\begin{tabular}{|l|}
\hline 1 - Electrical machinery, apparatus, energy \\
\hline 2 - Audio-visual technology \\
\hline 3 - Telecommunications \\
\hline 4 - Digital communication \\
\hline 5 - Basic communication processes \\
\hline 6 - Computer technology \\
\hline 7 - IT methods for management \\
\hline 8 - Semiconductors \\
\hline 9 - Optics \\
\hline 10 - Measurement \\
\hline 11 - Analysis of biological materials \\
\hline 12 - Control \\
\hline 13 - Medical technology \\
\hline 14 - Organic fine chemistry \\
\hline 15 - Biotechnology \\
\hline 16 - Pharmaceuticals \\
\hline 17 - Macromolecular chemistry, polymers \\
\hline 18 - Food chemistry \\
\hline 19 - Basic materials chemistry \\
\hline 20 - Materials, metallurgy \\
\hline 21 - Surface technology, coating \\
\hline 22 - Micro-structural and nano-technology \\
\hline 23 - Chemical engineering \\
\hline 24 - Environmental technology \\
\hline 25 - Handling \\
\hline 26 - Machine tools \\
\hline 27 - Engines, pumps, turbines \\
\hline 28 - Textile and paper machines \\
\hline 29 - Other special machines \\
\hline 30 - Thermal processes and apparatus \\
\hline 31 - Mechanical elements \\
\hline 32 - Transport \\
\hline 33 - Furniture, games \\
\hline 34 - Other consumer goods \\
\hline 35 - Civil engineering \\
\hline
\end{tabular}

